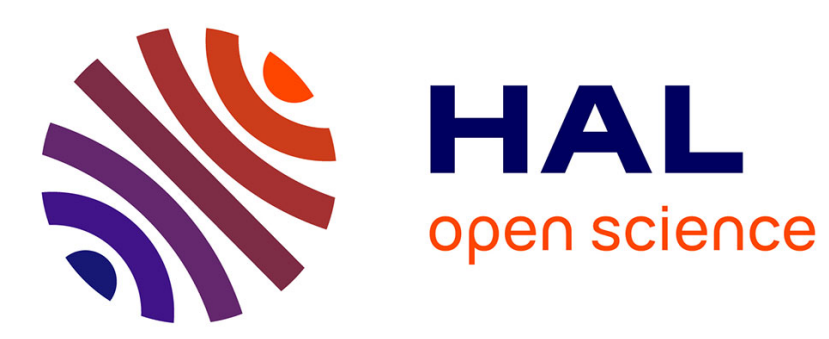

\title{
Pathways to archaic citizenship
}

Alain Duplouy

\section{To cite this version:}

Alain Duplouy. Pathways to archaic citizenship. Alain Duplouy; Roger W. Brock. Defining citizenship in archaic Greece, Oxford University Press, pp.1-49, 2018, 978-0-19-881719-2. hal-02404249

\section{HAL Id: hal-02404249 \\ https://hal-paris1.archives-ouvertes.fr/hal-02404249}

Submitted on 18 Dec 2019

HAL is a multi-disciplinary open access archive for the deposit and dissemination of scientific research documents, whether they are published or not. The documents may come from teaching and research institutions in France or abroad, or from public or private research centers.
L'archive ouverte pluridisciplinaire HAL, est destinée au dépôt et à la diffusion de documents scientifiques de niveau recherche, publiés ou non, émanant des établissements d'enseignement et de recherche français ou étrangers, des laboratoires publics ou privés. 


\title{
Defining Citizenship in Archaic Greece
}

\author{
Edited by \\ ALAIN DUPLOUY \\ and \\ ROGER BROCK
}




\section{OXFORD \\ UNIVERSITY PRESS}

\section{Great Clarendon Street, Oxford, OX2 6DP, United Kingdom}

Oxford University Press is a department of the University of Oxford.

It furthers the University's objective of excellence in research, scholarship, and education by publishing worldwide. Oxford is a registered trade mark of Oxford University Press in the UK and in certain other countries

\section{(c) Oxford University Press 2018}

The moral rights of the authors have been asserted

First Edition published in 2018

Impression: 1

All rights reserved. No part of this publication may be reproduced, stored in a retrieval system, or transmitted, in any form or by any means, without the prior permission in writing of Oxford University Press, or as expressly permitted

by law, by licence or under terms agreed with the appropriate reprographics rights organization. Enquiries concerning reproduction outside the scope of the above should be sent to the Rights Department, Oxford University Press, at the address above

You must not circulate this work in any other form and you must impose this same condition on any acquirer

Published in the United States of America by Oxford University Press 198 Madison Avenue, New York, NY 10016, United States of America

British Library Cataloguing in Publication Data

Data available

Library of Congress Control Number: 2017951885

ISBN 978-0-19-881719-2

Printed and bound by CPI Group (UK) Ltd, Croydon, CR0 4YY

Links to third party websites are provided by Oxford in good faith and for information only. Oxford disclaims any responsibility for the materials contained in any third party website referenced in this work. 


\section{Contents}

List of Figures and Tables $\quad$ ix

List of Abbreviations $\quad$ xi

List of Contributors xiii

1. Pathways to Archaic Citizenship 1 Alain Duplouy

2. State Formation in Early Iron Age Greece: The Operative Forces John K. Davies

3. Retracing Steps: Finding Ways into Archaic Greek Citizenship Josine Blok

4. Citizens and Soldiers in Archaic Athens Hans van Wees

5. Associations and Citizenship in Attica from Solon to Cleisthenes Paulin Ismard

6. Citizenship and Civic Subdivisions: The Case of Sparta Marcello Lupi

7. The Spartan Contribution to Greek Citizenship Theory Paul Cartledge

8. Athletics and Citizenship Nick Fisher

9. Citizenship and Commensality in Archaic Crete: Searching for the Andreion James Whitley

10. Citizenship as Performance Alain Duplouy

11. Oligarchies of 'Fixed Number' or Citizen Bodies in the Making? Maurizio Giangiulio

12. Conclusion: Taking Stock and Looking Backward Roger Brock 


\title{
1 \\ Pathways to Archaic Citizenship
}

\author{
Alain Duplouy
}

Citizenship is a major feature of contemporary national and international politics. It is also a legacy of ancient Greece. The concept of membership of a community appeared in Greece some three millennia ago as a participation in the social and political life of small-scale communities, but it is only towards the end of the fourth century BC that Aristotle offered the first explicit statement concerning it. Although widely accepted by historians of ancient Greece, the Aristotelian definition remains deeply rooted in the philosophical and political thought of the classical period, and probably fails to account accurately for the previous centuries and the dynamics of the emergent cities. Focusing on archaic Greece-intended here as the whole pre-classical era from the collapse of the Mycenaean palaces-our collective enquiry aims at exploring new routes to archaic citizenship.

Referring to the main primary sources, this introductory chapter explores some of the pathways that have been taken by historians and archaeologists over the last century in investigating Greek citizenship. It does not claim to be exhaustive and rather aims at echoing more extensive reviews. ${ }^{1}$ Through selected topics-the Aristotelian model, law and institutions, economy, terminology, and material culture-this first chapter offers an overview of milestone studies, with a focus on French literature (not always accessible to English-speaking scholars) and its distinctive approaches, notably the 'anthropologie historique' of the so-called 'École de Paris'. Several of the themes raised here will be discussed again in the following chapters, sometimes with diverging opinions. One of the purposes of the volume is precisely to exemplify the diversity of approaches to archaic Greece and to the Greek city, trying to keep away from the hidden dangers of a monolithic conception of archaic

1 E.g. Reinau 1981; Walter 1993; Scafuro 1994; Davies 2004; Cecchet and Busetto 2017. Of course, the specific literature on the Greek city is also related to the notion of citizenship; cf. e.g. Gawantka 1985; Sakellariou 1989; Vlassopoulos 2007; Ma 2016. 
citizenship. As Oswyn Murray warns us, 'the more coherent a picture of any aspect of society, the more false it is likely to be. ${ }^{2}$ There are many ways to think about archaic Greece, and the book is meant to mirror this variety of attitudes.

One of the first steps to consider in this survey-and probably one of the key issues in matters of archaic citizenship-is the relation between the city (polis) and the citizen (politēs). In 1970 the French structural linguist Emile Benveniste insisted on the existence of two opposite linguistic models of the ancient city, using the words that denote it as points of entry to understand and compare Greek and Roman citizen institutions. ${ }^{3}$ If the Latin word civis produced civitas, the word polités is conversely a derivative of the word polis. To put it another way, whereas in Latin only a gathering of citizens engenders a civitas, in the structure of the Greek language-as well as in English or in French - there is no citizen without a city. This linguistic derivation has often supported the view that early Greek cities were theoretical entities, "cities of reason' according to Oswyn Murray or Jean-Pierre Vernant. ${ }^{4}$ Their foundation is regularly attributed to an oikistēs (such as Phalantos for Tarentum) or a hero (such as Theseus for Athens) and they evolved thanks to various lawgivers or prominent individuals. Whether known or unknown to us, these founding fathers are considered as the creators of a political, juridical, social, institutional, economical, and religious core structure framing the ancient polis, therefore allowing politai to construct their citizen identity in relation to it. In this sense, citizenship is often conceived as a mere by-product of the process of state formation, that is, essentially as a 'membership' of a previously defined political entity. Accordingly, historians explain that, even if the polis already existed in archaic Greece, there were not yet politai. The issue of archaic citizenship is then reduced to a discussion about the city itself and its genesis. As Philip Manville briefly put it, 'the quest for the origin of the community will necessarily provide clues about membership in it'.

However, as Benveniste warned us, a linguistic derivation is not necessarily to be (mis)interpreted as an historical process. Vocabulary is itself a construction and words should be conceived primarily as a discourse on key institutions. Hence, the linguistic connection between polis and polités was only the way Greeks tended to conceive the relation between a city and its citizens, but not necessarily the way it arose and evolved.

Other historians, indeed, explain that the polis was primarily a community of citizens: 'men make the city' (ă $\nu \delta \rho \epsilon s \gamma \dot{\alpha} \rho \pi$ ó $\lambda(s)$, wrote Thucydides (7.77.7) following Alcaeus (fr. 112.10, 426), resolutely setting the stage of community making through the actions of individuals. Instead of 'membership', which

\footnotetext{
2 Murray 1990b, $4 . \quad 3$ Benveniste 1970; cf. Duplouy 2006b.

4 Murray 1990b; Vernant 1982.

5 Manville 1990, 35. See also Davies 1996a and this volume (chapter 2).
} 
introduces a view from the top, citizenship could thus be described as a kind of 'participation'- which is, incidentally, the very meaning of the word (metechein) used by Aristotle in defining it. When Alcaeus (fr. 130) portrays with tremendous bitterness his exile in contrast to a previous life as a citizen, he alludes to attending the assembly and the council, but also to political strife (stasis) between fellow citizens, tightly embedding the interactions between individuals at the core of the polis. In commenting on these famous verses Carmine Ampolo laid great stress on assessing citizens as 'azionisti della polis'. The reference to financial shareholding was deliberately made, as Ampolo extended the citizen participation to all socio-economic fields. Besides attending the deliberative institutions of the polis, the exercise of citizenship covers all the areas of collective activities (cults and rituals, public organizations and their imagined identities), as well as land holdings, shares in the profits of mines, etc. As Ampolo summed up, i cittadini non solo partecipano alla vita politica (pochi o molti dipendeva dal tipo di regime), ma alla vita civica in generale in tutti i suoi aspetti, in contesti che implicano una partecipazione agli utili, ai benefici'. 6 When considering citizenship as a 'participation' in the community, the issue about archaic citizenship therefore turns to exploring the various fields-political, economic, and social-in which individuals could be involved in the process of making and maintaining a polis.

Whether the contributors to this volume decide to consider citizenship as a 'membership' or as a 'participation', what is at stake is ultimately the nature of archaic cities, which also rests on historiographical choices.

\section{THE ARISTOTELIAN MODEL}

Defining citizenship is a problem that was explicitly stated for the first time by Aristotle in the Politics. He answered it in a theoretical way by emphasizing the functions and role of the citizen in the political and judicial institutions of the city-state. ${ }^{7}$

Before turning to a discussion of the various forms of constitution in Greek cities, with his well-known sixfold classification (kingship, tyranny, oligarchy, aristocracy, democracy, and politeia), Aristotle first inquires into the nature of the citizen. The first chapters of Book 3 (1274b-1278b) are thus devoted to a definition of citizenship. Who is entitled to the name of citizen? He first notes the great diversity of actual conceptions in different cities: 'often somebody who would be a citizen in a democracy is not a citizen under an oligarchy'

\footnotetext{
6 Ampolo 1996, 322.

7 See the classic studies by Mossé 1967b; Lévy 1980; Johnson 1984. More recently, Osborne 2011, 88-91; Blok 2017.
} 
(1275a3-5). He then discards various inadequate criteria, such as the place of domicile or the right to participate in a judicial system, and disqualifies several borderline cases-which might have been current in his time-such as honorary citizens, under-age young men, the elderly discharged from military obligations, or disenfranchised and exiled citizens. As a theoretician, Aristotle is mainly looking for a definition of citizenship that would be universal despite the great political diversity among Greek states. As he puts it, he seeks to define the citizen in an absolute sense ( $\left.\pi \circ \lambda i_{i} \tau \eta \delta^{\prime} \delta^{\prime} \dot{\alpha} \pi \lambda \hat{\omega} s, 1275 \mathrm{a} 19\right)$. According to Aristotle, this pure and simple citizen is to be defined as 'a man who shares

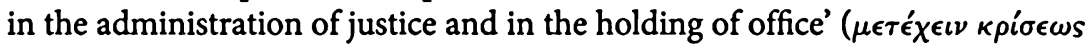
кai a $\rho \chi \hat{\eta} s, 1275 \mathrm{a} 23)$. Among the archai he includes the offices with fixed terms, whether or not they can be held several times, as well as the offices without limit of tenure, such as juryman in courts and member of the assembly. Accordingly, he asserts that citizens are those who participate in

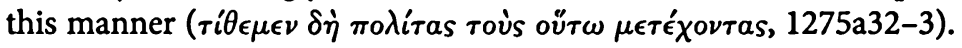

Having stated this extremely abstract but supposedly universal definition, Aristotle then engages in a subtler discussion on historical and political variability. Since he is going to define various forms of regime, he admits that the kind of citizenship corresponding to each form of constitution will necessarily be different. He also acknowledges that his definition especially applies to democracies, but does not suit other forms of government as well. The first definition has thus to be corrected to account for those regimes in which deliberative and judicial duties are assigned to restricted boards or designated magistrates, and not to the whole body of citizens such as a popular assembly. Amending his original definition, Aristotle eventually states that a citizen is 'the one who has the right to participate in deliberative or judicial

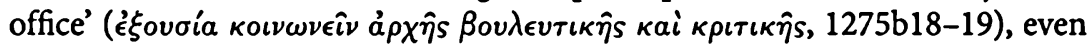
if he does not continuously exercise these offices as he would in a democracy.

He then discusses transmission of citizenship and the durability of the city. If the citizen body is usually equated with a 'descent group', citizenship being normally limited to the children of citizens on both sides-although he later (1278a27-34) discusses less restrictive rules-there were other alternatives of enfranchisement, such as special magistrates entitled to be citizen-makers. More practically still, since descent from a citizen father or a citizen mother does not apply to the first inhabitants or founders of a city, whoever practises citizenship in the way previously stated is a citizen. Concerning the enrolment of new citizens by lawgivers or powerful politicians, the question can arise whether they received their citizenship wrongly or rightly. Since the validity of the definition acknowledging the power of the ruling citizens is not affected by having the officials governing rightly or not, even persons wrongly admitted to citizenship are nevertheless to be considered as such. Aristotle further introduces the debate over the identity of and relationships between the (provisional) rulers and the (timeless) state. With time passing and parameters 
changing (population, size, ethnicity) would a city indeed always be the same city? This is a difficult question, which has no simple answer according to the philosopher. However, stressing as he does politics and constitutional matters, he asserts that when the form of the government has been altered

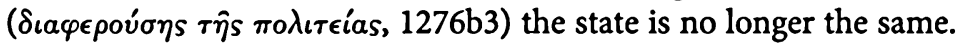

Aristotle then goes on to define the value (aretē) of a good citizen, as distinct from the value of a good man. Of course, in Aristotelian thought, the value of a citizen is related to the constitution of the state. And since there are various forms of constitution, there is not a single form of citizen goodness, while being a good man is an absolute quality. It is even possible to be a good citizen without being a good man, and it is not necessary that all the citizens in a state be good men. Aristotle introduces here a distinction between two sorts of citizen, the ruler (archōn) and the ruled (archomenos), only the former having to be a good man. If a good ruler knows how to exercise his authority, the good citizen must also learn to obey, that is, to be ruled. There are thus two ways to have a share in politics or two moments in politics, archein and archesthai, to rule and to be ruled. The value of a good citizen consists in his ability to rule and be ruled alternately. This means that the ruler should also learn by being ruled: it is impossible to become a good ruler without having been a subject. Conversely, the good citizen should be able to rule, which might be an issue if he lacks the virtue of a good man.

Before turning to the discussion of the various forms of constitution, Aristotle supplements his thinking on citizenship by taking an actual example of the relationship between these two levels of citizenship. Can workers be counted as citizens? Since artisans are not capable of governing because of their lack of virtue, should they be considered as citizens? According to Aristotle, in ancient times craftsmen were regularly excluded from the citizen body and so the best-ordered polis should not enfranchise any of them. If workers or craftsmen are citizens, the citizen's virtue, as previously defined, would not be valid for every citizen, but only for those who are released from menial occupations. Depending on the kind of constitution, artisans will therefore be counted in or excluded from citizenship. In aristocracies, since honours are bestowed according to merit and dignity, no one living a life of manual labour can have a share in citizenship, whereas in oligarchies, in which admission to office is based on property assessments, rich artisans can be citizens. However, according to Aristotle, if workers are enfranchised, they can be nothing else than ruled citizens or subjects (archomenoi politai).

In sum, if there are various kinds of citizens, according to Aristotle, a 'citizen in the fullest sense' is the one 'who shares in the offices' ( $\mu a \lambda_{\iota} \sigma \tau a$

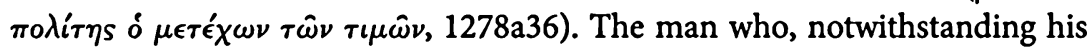
citizen status, does not have a share in the honours of the polis-that is, the ruled citizen, as opposed to the ruler-is like a metic ( $\left.\dot{\epsilon} \sigma \tau \iota \nu \dot{o} \tau \hat{\omega} \nu \tau \iota \mu \hat{\omega} \nu \mu \dot{\eta} \mu \epsilon \tau \epsilon^{\prime} \chi \omega \nu, 1278 \mathrm{a} 38\right)$. Of course, this thinly disguised 
criticism of contemporary Athenian democracy makes clear how restricted the pure citizen is intended to be in the Aristotelian model.

Having synthetically recorded Aristotle's approach to citizenship, we must also recall the political and intellectual context in which it was formulated. As Josiah Ober seminally described it, ${ }^{8}$ after the collapse of the brief oligarchy of 403, elite Athenian critics of popular rule set themselves the arduous task of explaining what was wrong with the power of the people and of inventing alternative visions of (mostly) non-democratic political societies. After Ps.-Xenophon's pamphlet, Plato's writings and Isocrates' speeches, Aristotle's political philosophy still sought to formulate practical internal amelioration of existing regimes, as well as to influence the political organization of future Greek cities in the hope of building the best imaginable politeia. In his task, Aristotle often embraces the model of a moderate democracy, but also promotes various strikingly aristocratic ideas and features, as well as taking a radically critical stance towards democracy as it was currently practised. Not surprisingly, the Aristotelian definition of citizenship has the tone of this wider political perspective.

\section{THE LEGAL AND INSTITUTIONAL APPROACH}

Since Aristotle is the only ancient author to offer a clear-cut definition of citizenship in ancient Greek cities, his thought has long been the starting point of any reflection on the nature of citizenship-and, of course, on the ancient Greek polis, since 'a state is a collection of citizens', $\dot{\eta} \gamma \dot{\alpha} \rho$ mó $\lambda \iota s \pi o \lambda i \tau \omega \nu \tau \iota$ $\pi \lambda \hat{\eta} \theta o^{\prime}$ ' $\dot{\sigma} \sigma \tau \iota \nu$ (Pol. 3.1274b41). Given how embedded the Aristotelian citizen is in the discussion of the various forms of constitution, his definition of citizenship has been at the core of a long tradition of political and legal studies, beginning with the German historians of the late nineteenth century and their Griechische Staatskunde and ending with the Copenhagen Polis Centre and its Inventory of archaic and classical poleis.

Following the model of Theodor Mommsen's Römisches Staatsrecht (1871-88), German historians of the late nineteenth and early twentieth centuries engaged in a legal and institutional description of Greek states. Deploring the fact that, even for classical Athens, sources are not as numerous and explicit as the corpus of Roman law, they carried on Aristotle's theoretical inquiry. According to his own words, Emil Szántó claimed to be the first since Aristotle to propose a comprehensive and systematic study of Greek constitutions in his Griechische Bürgerrecht (1892). Because the city is described as

8 Ober 1998, 290-351. 
the sum of all the citizens, Szántó set at the core of his inquiry on the Greek state an investigation of the citizen: 'Wer also die Frage gelöst hat: Was ist der Bürger? der hat für die griechischen Demokratie auch die Frage gelöst: Was ist der Staat. ${ }^{\text {'9 }}$ Following the ancient master, he further developed the question of political authority (archē) by collating the rich collection of inscriptions from the entire Greek world on various legal matters related to civic rights, particularly enfranchisement, isopoliteia, and sympoliteia. Of major importance were also the two volumes of Griechische Staatskunde in the Handbuch der Altertumswissenschaft: Georg Busolt offered a general description of Greek states, followed by Heinrich Swoboda's study on Sparta, the Cretan cities, and Athens. ${ }^{10}$ They were mainly interested in the conditions of citizenship enrolment and by the exercise of deliberative, legislative, and judicial authority that constitutes the exclusive privilege of citizens. They discussed transmission of citizenship and ways of enfranchisement, as well as the various institutions of the polis (assembly, council, and courts) and their oligarchic or popular recruitment. Through a theoretical account derived from ancient political thought and exemplified by numerous case studies emerges the idea of a continuous development from early states to democratic poleis, where archaic cities are mainly characterized by a much more reduced number of full citizens than democratic states.

This Mommsenian tradition, which gave rise to numerous studies during the past century, combines two approaches to Greek citizenship that can be analytically distinguished: the first explores the citizen status and its legal privileges in contrast to various non-citizen statuses, the second analyses the evolution of political institutions among Greek cities and produces a constitutional account of Greek history.

Greek citizenship has regularly been thought to embody an overall legal status associated with various rights and duties: the right to attend the assembly (and sometimes to speak and vote), to hold public offices, to take part in the civic religion, to have full access to justice and serve as juror in courts, to buy and own land, but also to defend the community during wars and pay taxes. In this sense, its legal boundaries were also drawn in opposition to various groups of non-citizens. Classical Athenian law for instance distinguishes politai from foreigners (xenoi), resident aliens (metoikoi), and slaves (douloi). As Virginia Hunter puts it, 'Resident aliens and Athenian citizens were each a juridically defined group with privileges, on the one hand, and disabilities, on the other, enshrined in law. These two social groups together with a class of slaves represent the three "orders" of Athenian society." ${ }^{11}$ With such a tightly defined and regulated status, the citizen body appears as a closed social order. Apart from some individuals (freedmen or foreigners) who were

9 Szántó 1892, 5. $\quad{ }^{10}$ Busolt 1920; Swoboda 1926.

11 Hunter 2000, 1. See also Fisher 2006. 
exceptionally granted citizenship for their civic commitment, ${ }^{12}$ being a citizen in an ancient Greek city was an exclusive privilege. As a legal status, citizenship was protected by inherited rights. Its transmission was restricted to ius sanguinis, so that the citizen body normally formed a 'descent group': only sons of a citizen father (and sometimes both of a citizen father and of a citizen mother) were admitted to the citizen body. ${ }^{13}$ There was therefore a kind of civic blood, and lacking it, it was nearly impossible to cross the barrier to citizenship. For the privileged people who enjoyed this status, its transmission was expected and (nearly) automatic, even if ritually controlled through various social and legal institutions. In Athens again, young males of citizen parentage on both sides were registered on the rolls of their demes at the age of eighteen, provided that they complied with the strict rules for Athenian citizenship. After the successful co-optation by their fellow demesmen and the approval by the council, their names were inscribed in a register kept by the deme, the lexiarchikon grammateion. The affiliation to a sub-unit of the city (such as the demes or the phratries) was a necessary and sufficient condition of membership of the city. As Philip Manville concludes, 'Athenian citizenship in its various legal aspects can be described as a formally instituted status group. ${ }^{14}$

Most of these studies are related to classical Athens and it is indeed much more difficult to trace back these rules and principles into archaic Greek cities. In their anthology of political and legal inscriptions of archaic Greece (Nomima), Henri Van Effenterre and Françoise Ruzé collected the few inscriptions pertaining to citizen status from the entire Greek world. Apart from a few late seventh-century fragments of Gortynian regulation, most of them are late archaic texts-between 530 and 450, with a majority around 500 -that throw no light on earlier legal conceptions of citizenship. There is indeed no link between these late archaic inscriptions, covering a timespan of no more than eighty years, and the so-called age of the lawgivers (Lycurgus of Sparta, Solon of Athens, Zaleucus of Locri, Charondas of Catania, etc.) of the seventh and early sixth centuries. Moreover, in the epigraphic sources, there is no factual description of a citizen status stating every right and duty of their holders, but only allusions to privileges that are usually denied to nonmembers of the citizen community or granted to newly enfranchised citizens. As various recent studies tend to show, Greek archaic laws did not have the normative function of Roman rules and regulations, as often assumed by the earlier German Griechische Staatskunde, but were usually enacted or written with the pragmatic aim of settling disputes or negotiating positions between members of the community. ${ }^{15}$ As Van Effenterre and Ruzé explain, the citizen identity in archaic Greece was primarily defined in contrast to other statuses.

\footnotetext{
12 For Athens, see Osborne 1981-3.

13 Davies 1977.

14 Manville 1990, $13.1{ }^{15}$ Hölkeskamp 1999, 262-9; 2005.
} 
Membership of a Greek polis involved very different features from one city to another (place of residence, means of living, personal attachment, or services rendered to the community, etc.), but most often citizens initially appear in opposition to foreigners (xenoi) of all kinds, whether travellers, traders, beggars, craftsmen, friends, intruders, refugees, or assailants. According to the few known late archaic regulations, individuals or small groups could be integrated or reintegrated into the citizen community with (some of) the attendant privileges: tax exemption (ateleia), property holding or land allotment, legal protection against enslavement or property confiscation (asyleia), access to public offices, enrolment in a men's club (Cretan andreion), or participation in civic rituals. 'Ainsi, ce dont le citoyen d'origine bénéficie par nature, et que l'étranger naturalisé acquiert, c'est la double sécurité des personnes et des biens,' comments Ruzé. ${ }^{16}$ She further adds, 'le pouvoir délibératif est consubstantiel à la citoyenneté; il est le droit propre au citoyen, le minimum de ce qui lui est reconnu: ayant éliminé tout autre critère de citoyenneté, Aristote s'en tient à celui-là'. ${ }^{17}$ It is therefore supposed that the evolution of citizenship closely follows the development of deliberative boards and the change in forms of government. Aristotle's questioning on the citizen does introduce, indeed, an investigation of the various political regimes and their evolution.

Aristotle's political thought is well known: if rulers rule for the common interest, constitutions are necessarily good; if they rule for their own interest, constitutions are deviations (Pol. 3.1279a-b). The 'correct' (orthai) forms of government are those which have the welfare of the governed at heart, whereas those who aim only at the rulers' good are 'deviations' (parekbaseis). Adding to this principle the usual criterion of the number of rulers, Aristotle defines six forms of government, which constitute the core of the whole of ancient and modern political thought, from Dicaearchus and Polybius to Victor Ehrenberg and Mogens Hansen. Kingship, aristocracy, and 'citizenconstitution' (politeia) belong to the good regimes, and the 'deviations' are tyranny, oligarchy, and radical democracy. This political taxonomy was developed alongside a historical conception, producing an institutional account of the past. According to ancient political thought, each kind of government was assigned to a specific period. In the remotest past, in the time of heroes and of foundation of cities, kingship was the regular form of government. With time, there were more men equal in virtue so that aristocracy succeeded to kingship after a revolution. Soon people got more and more interested in money and neglected the common wealth; rulers became oligarchs. Those regimes evolved to tyranny when one of the rulers, searching support from the masses, monopolized the head of the state. But when people got tired of an

16 Van Effenterre and Ruzé 1994; Ruzé 1997, 354; 2003b, 169-70.

17 Ruzé 1997, 405-6. 
autocratic rule, a revolution marked the transition to democracy. Monarchy, aristocracy, oligarchy, and tyranny were thus classified as typical systems of the archaic period, and democracy was thought to be characteristic of the classical period. The general principle-supported by Aristotle's teleological tendencies-is that of a constant widening of the number of rulers, but also of the worsening of the government towards its negative variant. ${ }^{18}$

The Aristotelian constitutional frame has of course direct consequences for the definition of archaic citizenship. As stated by Gustave Glotz, the major difference between these forms of government lies primarily in the distribution of power between institutions, not in the nature of the institutions themselves: in aristocracies and oligarchies, political authority belongs to the council and its members, whereas in democracies it lies in the hands of the assembly and an enlarged citizen body. ${ }^{19}$ By definition, in archaic poleis, citizens fully performing the political privileges inherent to their status were thus very few. In this sense, any modern political definition of archaic citizenship follows, often closely, considerations of an archaic social order, in which aristocrats and noblemen, usually associated with wealthy landowners, were supposed to rule archaic cities. In a way, archaic citizenship is reduced to a matter of social access to political institutions.

This institutional approach to the Greek city-as well as to citizenship-has been revived recently thanks to the wide audience of Mogens H. Hansen's masterly and prolific work. ${ }^{20}$ Assembling an inventory of all known Greek poleis in the archaic and classical periods, Hansen carried out an extensive analysis of the ancient concept and realities. One of the essential characteristics of the whole work of the Copenhagen Polis Centre is to favour an institutional definition of the Greek city-state, which is primarily conceived as a political community. According to Hansen, 'the polis was a highlyinstitutionalised community, and at the core of the polis were the political institutions where the politai met and isolated themselves from women, foreigners and slaves. Political activity was a fundamental aspect of the community, and, as a polity, the polis is best seen as a very deliberately planned and highly rational form of political organisation. ${ }^{21}$ This conception was explicitly set against a holistic-that is, French or Durkheimian ${ }^{22}$-view of the polis, in which religion and cults are considered as important aspects of community life and accepted as structural features in the process of state formation. According to Hansen, however, there is a clear-cut distinction between the polis sphere and a religious sphere that was not institutionally

18 For more details, see e.g. Duplouy 2005.

19 Glotz 1928, 94. This conception is still present in more recent French historiography, see for example Mossé 1984a.

${ }_{20}$ Hansen and Nielsen 2004; more synthetically, Hansen 2003.

${ }^{21}$ Hansen 2003, 264 (no. 25).

22 Cf. Murray 1990b. See also Polignac's response to Hansen's approach (Polignac 1995b). 
organized. The core features of a city-state therefore lie in its political institutions, which offer a sound basis for the definition of a citizen's activity and status. As Hansen clearly writes it, 'the very heart of the polis concept was the citizen body understood as the participants in the city's political institutions' and therefore 'a citizen is defined as a person (politēs) who takes a part in the running of a polis by exercising his political rights'. More precisely, 'in the ancient Greek city-state culture "citizenship" was what it has become again in the modern world: a person's juridically defined, inherited, membership of a state, in virtue of which that citizen enjoys a number of political, social and economic privileges in that state which a non-citizen living in the state is deprived of or can enjoy only to a limited extent. ${ }^{23}$ Aristotle is very frequently quoted in Hansen's work and is supposed to offer a viable definition of citizenship for both classical and archaic poleis, often making the Inventory of archaic and classical poleis a mere revival of nineteenth-century Griechische Staatskunde.

Numerous scholars have been happy to accept Aristotle's political model as a guide to delineate Greek citizenship, even back into the archaic period. Unfortunately, since Greek history is often reduced to changes in forms of government, such an approach to citizenship usually avoids any historical discussion of the citizen status. Being defined as a primarily legal status, politeia is meant to be a timeless and static concept, unchanged throughout centuries except for minor revisions of various statutory details. Insofar as a distinction is considered between the archaic and the classical period, archaic citizenship is most often described as an incomplete or restricted status.

One of the major difficulties in writing archaic history is probably to construct a vision of archaic Greece independent of classical history. As a kind of (unconscious) commitment to Hegelian teleology, indeed, historians often tend to regard archaic poleis as a form of unaccomplished or primitive classical city. Archaic citizenship is therefore compared to an ideal stage of politeia that would be the political and judicial status defined by classical thought, as the late nineteenth-century tradition and more recent scholarship have accepted it. If a legal and institutional definition of the citizens' duty conveniently fits the political structure and mechanisms of many classical democracies, as well perhaps as some early Hellenistic poleis, it does not always fit archaic realities and concepts so precisely. But since many archaic cities were not as strictly institutionalized as classical Athens, archaic citizenship has been regularly qualified as 'incomplete' or 'elementary'.

To quote Philip Manville, Athenian citizenship was 'a mere glimmer in the age of Drakon, born under Solon, nurtured by tyrants, and given full form by Cleisthenes'. ${ }^{24}$ Addressing the origins of citizenship in ancient Athens,

${ }^{23}$ Hansen 2006, 110-12.

24 Manville 1990, 209. 
Manville introduces his work with a quotation of Demosthenes' Against Neaira and first details all major aspects of citizenship in classical political thought and practice. But what did it mean before the age of democracy? To understand the origins of membership of the city-state, Manville investigates the origins of the polis itself and the stages through which it passed before it became the classical form of state in Pericles' days. Defining citizenship here becomes a by-product of the reflection on the polis itself, in agreement with Benveniste's linguistic model. In search of a definition of the emergent polis, he immediately considers Aristotle's Politics, adopting the constitutional model that has the Athenian city successively passing through monarchy (Theseus), oligarchy (from Draco to Solon), tyranny (Peisistratus), and democracy (Cleisthenes). According to Manville and his Aristotelian framework, earlier stages of Athenian history were mainly characterized by a decentralized social mosaic, in which the diversity of affiliations to local villages and regional corporations long prevented the emergence of a common self-conscious unity among the Attic population. The gradual consolidation of citizenship in archaic Athens therefore appears as the results of enduring centralizing trends. A fully developed citizenship eventually emerged with the creation by Cleisthenes of a uniform system of membership of the city-state thanks to a new pattern of local demes. Besides discussion of ancient sources that chronicle a series of changes in institutions and citizen affiliations, much of the inspiration of Manville's study explicitly derives from the work of neoevolutionist anthropology, which sets a standard of evolutionary patterns to the development of primitive states. ${ }^{25}$ In this sense, archaic citizenship appears as a primitive stage on the way to a more complete and formal political status of citizen, namely membership of the classical and democratic city. It is however important to note that, even if neo-evolutionism has inspired various works on archaic Greece in recent years, ${ }^{26}$ it has also been increasingly subject to criticism in the field of anthropology. Scholars notably insist on its inadequacy for the study of evolutions over small timescales: if ever sustainable as an interpretive model, it only applies to long-term diachronic perspectives, such as a millennium, but certainly not to the few decades of Athenian constitutional history from Draco to Cleisthenes. ${ }^{27}$

Such a teleological approach to archaic history also undermines Christian Meier's idea of the late emergence of a 'true citizenship' through the institutional and cultural revolution of Cleisthenes. ${ }^{28}$ According to the German historian, the 'true citizen' emerged when the 'political' became established as a separate political order, split off from the social order and set over against it, with state institutions that were divorced from society. This happened

25 On neo-evolutionist anthropology, Johnson and Earle 1987 [2000].

${ }^{26}$ For example, Edwards 2004 and my review in AC 75 (2006), 522-3.

27 Yoffee 1993; McIntosh $1999 . \quad{ }^{28}$ Meier 1990. 
during the classical age, especially in the democracy of Athens, when the rights and freedom of every citizen were constitutionally secured. According to Meier, when broad sections of the citizenry assumed a political role thanks to the Cleisthenic reforms, the citizens finally met as citizens, saw themselves as citizens, and relied on one another as citizens. This formal citizen status is presented as the final stage of a natural evolution, but archaic history is somehow abridged as if it were a mere movement towards democracy.

In their masterwork Nomima, Henri Van Effenterre and Françoise Ruzé coined the concept of pre-politeia to describe the content of archaic citizenship. The word politeia itself first appears with the meaning of 'citizenship' in classical sources. Herodotus (9.34.1) uses it to qualify the status requested by Teisamenos from the Lacedaimonians, and it is by far the most common meaning attested all over the Greek world in hundreds of late classical and Hellenistic decrees granting citizenship. ${ }^{29}$ According to Van Effenterre and Ruzé and in agreement with Benveniste's linguistic model, if there were cities in most parts of the Greek world, there were not yet citizens; the concept of citizenship was not yet outlined: 'Ce que nous appelons pré-politeia n'est aucunement un statut précis qui aurait précédé la citoyenneté classique. C'est, sur un siècle et demi, du viI ${ }^{e}$ au v ${ }^{e}$ siècle, la confluence d'efforts dispersés qui permettent de dégager peu à peu le rapport fondamental entre l'homme et la cite. ${ }^{30}$ Until the fifth century there was no formal legal status of citizen. To say it in a less subtle way, there was no classical citizenship before the classical period!

In a major study on the growing role of associations in the making of the Athenian polis (also synthesized in this volume, chapter 5), Paulin Ismard recently pursued Manville's insight about centralizing trends in citizen connections with the manifold social groups of the archaic and classical city. Ismard lays great stress on the active role played by associations-in the broadest sense, including phratries, gene, orgeones, thiasoi, etc.-in the shaping of Athenian citizen identity. He also insists on its gradual transformation from Solon to Cleisthenes and Pericles. For the whole of the sixth century, integration into citizenship passed through membership of one or several of the numerous associations existing inside the Athenian community. The same is true for late sixth- and early fifth-century Cretan cities: various inscriptions let us know that individuals were granted citizenship through the intermediary of a specific community of the city. This process of affiliation with the archaic city characterized what Ismard calls 'une citoyenneté encore largement inachevée', made up of elementary rights, 'qui n'a pas encore de lieu propre bien établi ni de contenu institutionnel stable, révélant le manque d'intégration politique de la cité du vi ${ }^{e}$ siècle. ${ }^{31}$ By contrast, the Cleisthenic reorganization

29 Bordes 1982, 49-107.

30 Van Effenterre and Ruzé 1994, 25-8.

31 Ismard 2010, 43, 77-8. See also Ismard this volume, chapter 5. 
of the demes brought a new and unique system of civic affiliation. The integration of all citizens in the deme and phratry structures set a common standard for the equal distribution of political rights and legal protection. This new civic framework of the late sixth century created the conditions for a new definition of citizenship, which would still have to wait for the Periclean law of 451/450.

It is obvious that archaic and classical citizenships were different in both theory and practice, although the latter could have retained some components of the former. Is it, however, historically sound and indeed useful to speak of an 'incomplete' archaic citizenship? In this sense, archaic citizenship is defined in contrast to another model, supposed to be more complete, by pinpointing its deficiencies, not by stressing its peculiarities. Is it really what we need?

As John Davies warns us, this disparaging attitude towards 'archaic' Greece is a typical trap: as often, terminology and periodization mislead more than they help. ${ }^{32}$ More radically, speaking of an 'incomplete' archaic citizenship complies with a teleological perspective and eventually sounds like a value judgement on an 'early' or 'primitive' city, both trends that should normally be avoided in the writing of 'archaic' history. Rather than considering that every reform of the citizen status was a step further on the way to a formal classical politeia intended as a final stage (at least before the Hellenistic era and the alleged decline of citizenship), we should perhaps acknowledge that the development of archaic social institutions into classical models was unpredictable. As Josine Blok puts it, 'the differences between the polis-structures in the early seventh and in the late fourth centuries are such that any relationship between the former and the latter cannot be explained with recourse to an underlying institutional continuity. Instead, the "rise of the polis" should be approached as an open process, which at some points might have yielded quite different results than the ones so well-known from fifth and especially fourth century sources. ${ }^{33}$ Historians should neither be judges, evaluating the archaic period in terms of classical models, nor seers, considering the future to explain the past. There is no doubt that citizenship was an evolving concept, but there is no profit or historical achievement in speaking of an 'incomplete' status for archaic Greece, nor in asserting the non-existence of citizens in archaic poleis.

Besides the so-called elementary content of archaic citizenship, another fundamental question is that of the 'extent' of political rights: who had citizenship in archaic Greece? and what sort of citizenship? Even if a political and legal status in some way equivalent to the classical formal citizenship ever existed in archaic Greece-a status that historians usually name 'full

32 Davies 2009, 3-4.

33 Blok 2005, 8. See also Blok 2004, 9-10, challenging the paradigm of institutional evolution, which searches for political institutions in elementary form at earlier stages of the polis. A similar perspective is adopted by Davies this volume (chapter 2 ). 
citizenship'-its social extension is regularly supposed to have been very restricted. Once again, Aristotle offers a philosophical explanation of this model. As we saw, according to him, there are two sorts of citizens, the ruler (archōn) and the ruled (archomenos). In a democracy, citizens are alternately one and the other, but in other forms of government, all deliberative and judicial offices are in the hands of a few individuals while most of the citizens never actually have a share in the honours of the polis and are therefore in a position of permanent inferiority. Since archaic cities were usually not considered as democracies, most archaic citizens could not be considered, therefore, as citizens in the fullest sense.

The Aristotelian conception formed the basis of a sharp distinction in modern historiography between two levels of citizenship. The widely accepted notion of 'full citizenship' (Vollbürgerschaft) has been traditionally applied to archaic history in order to describe the political rights of almighty aristocrats in contrast to the nearly institutional and judicial incapacity of 'underprivileged citizens' of the dèmos. This distinction between two sorts of citizens in archaic Greece holds a central place in all Griechische Staatskunde of the early twentieth century, but finds also an echo in numerous recent studies on archaic Greece, particularly (but not only) on Spartan society. ${ }^{34}$ Among others, Mogens Hansen has reasserted it in various studies: 'in relation to the structure and function of the state [...] citizens fall into two opposed groups: rulers and ruled, the first being identified with the government and the second with the subjects'. ${ }^{35}$ According to this model, only full citizens possessed unrestricted rule in the state. Besides women who never achieved a complete citizen status and young men who were not yet full citizens, the citizens of lesser rights were limited in their political status by social or financial restrictions. They could be admitted to the assembly, as the thettes in the Athens of Solon, but were not expected to speak (or even to vote) and were excluded from all political or judicial offices. ${ }^{36}$ As Françoise Ruzé puts it, 'l'expression de la citoyenneté totale, à l'époque archaïque, se fait volontiers par la mention de l'égalité de droits avec les magistrats, ${ }^{37}$ thus assuming an identification between archaic full citizens and the Aristotelian ruling citizens. In many places, manual workers-when not excluded from citizenship-were likewise limited in their rights. In a historical perspective, with the extension of democratic government more citizens were supposed to enjoy full citizen rights: as Georg Busolt wrote, 'Die Verbreitung des minderechtigten

34 Busolt 1920, $\$ 48$ (Die Oligarchie des Adels und die der Begüterten); Swoboda 1926, $\$ \$ 70-2$ (Der Staat der Lakedaimonier: Die Rechtsstellung der verschiedenen Bevölkerungsklassen); Glotz 1928, 78; Ehrenberg 1969, 41-3; Welwei 1998, 93-110; Pomeroy et al. 2004, 70.

${ }_{35}$ Hansen 1994; 2002b; 2003, 265 (no. 30); 2006, 107-9 ('full citizens are only a part of all adult citizens').

36 As stated by Raaflaub 2006a, 423.

37 Ruzé 1997, 205 n. 9 referring to Nomima I, nos. 21 and 22. 
Bürgertums wurde immer weiter eingeschränkt, je ausgedehntere Geltung das demokratische Prinzip erlangte. ${ }^{38}$ Since democracy was the rule of the whole people, all citizens were full citizens in democratic cities. It was also the only form of government in which potential citizens equated so closely to actual citizens. In a certain sense, archaic history in its progress to democracy could thus be summarized as a continuous effort to grant full citizenship to all the citizens of a polis. As Claude Mossé once wrote, archaic Greece saw 'l'élargissement du corps civique, ou plus justement, du corps politique', that is, the extension of full citizenship to former underprivileged citizens. ${ }^{39}$

Like the theorization of an incomplete citizenship, such a distinction between two sorts of citizens is merely an alternative to the conventional idea that archaic citizenship was mainly incomplete or unachieved. In twentiethcentury historiography this distinction was also meant to anchor on a legal basis the alleged genetic inequalities between the demos and the nobility of the gene that was supposed to rule archaic cities: aristocrats were presented as full citizens and people from the demos as second-class or underprivileged citizens. Yet, a number of studies have long demonstrated that the construction of hierarchies in archaic and classical societies was in no way related to any legal or gentilician criteria. ${ }^{40}$ Likewise, the distinction between two levels of archaic citizenship is first and foremost the product of a political thought and practice deeply rooted in fourth-century Athenian politics that has been anachronistically applied to earlier times. ${ }^{41}$ The idea of two levels of citizenship arose in the rich political thought following the two Athenian oligarchic revolutions of the late fifth century, which also gave rise to the Aristotelian model. Rather than promoting an overthrow of the democratic order and the restriction of the citizen body to five or three thousand citizens, some moderate reformers or oligarchic sympathizers, such as Isocrates, urged the re-establishment of an ancestral democracy (patrios politeai) associated with the name of Solon, in which the wealthy rule the city alone but under scrutiny by the demos. Focusing on the ways in which democracy could be moderated, Isocrates points the way to a distinction, which was to appear in Aristotelian thought, between two sorts of citizens, archontes and archomenoi politai: on the one hand those who take part in the allotment of political offices, and on the other hand those who are always ruled. Elaborated by fourth-century political thinkers, such a distinction is probably not the most accurate model to account for the historical and political facts of previous centuries, even when it refers to an alleged ancestral constitution in pre-classical cities. There are actually no positive signs of a clear-cut step between two legally defined levels of citizenship. As Benedetto Bravo once demonstrated, 'nessuno dei testi

\footnotetext{
38 Busolt 1920, 221. 39 Mossé 1967a, 8.

40 From Bourriot 1976 to Duplouy 2006a.

41 Mossé 1967b, 21; 1979b; 1984b; Duplouy 2011.
} 
dell'età arcaica, né di quello posteriori, relative a quell'età, né, del resto, alcuno dei testi riguardanti le poleis dell'età classica o ellenistica, mi sembra attestare l'esistenza di un concetto in qualche modo analogo a quello romano di cives sine suffragio', concluding that 'all'interno di questo gruppo [the dèmos as a political body] esisteva una gradazione dei diritti politici, varia a seconda delle poleis e dei tempi; ma la nozione di "cittadino" non ammetteva alcuna gradazione: o si era cittadini, o non lo si era, assolutamente ${ }^{42}$ To be a citizen or not to be a citizen, that was the only question, with no gradation in the answer.

The excessive emphasis on legal and institutional matters has produced models that supposedly apply to all periods, from archaic to classical times, and all cities. Unfortunately, the results of this theoretical effort have generated anachronistic definitions of archaic citizenship, as well as an unjustified distinction between two sorts of citizen. More cautiously, recent scholarship has become increasingly sceptical of legal categories, even when applied to statuses of the classical and democratic city. ${ }^{43}$ In order to reassess the value of historical variability over the centuries, beyond any legal, political, or philosophical approach, scholars need to look for a genuinely archaic definition of citizenship or at least forge new models stemming from archaic realities. Wealth and the power of wealth are a good theme to start with.

\section{THE POWER OF WEALTH}

If social status has often been related to the economic debate, and notably to the way status interacts with wealth, ${ }^{44}$ citizen rights cannot as easily be linked to the nature of economic activity in archaic Greece. Except for a few facts, inferences are often drawn from logical or theoretical assumptions, rather than from unambiguous sources. There has been a protracted debate over the nature of the ancient economy. Was archaic Greece a world of subsistence farmers ruled by a landed elite with no interest in making money or was it dominated by farmer-traders producing a large proportion of their crops to sell abroad at the most favourable rate? Was the economy of archaic Greece heavily dependent on trade or was it based on self-sufficiency, limiting exchanges to reciprocity and gift-giving? Considering the relative scarcity of the written sources and the equivocal evidence offered by the archaeological material, the debate between 'primitivists' and 'modernists'-or more specifically between 'substantivists' and 'formalists'-depends ultimately on how archaic Greece is imagined. This is not the place to detail once again the

\footnotetext{
42 Bravo 1996 (quotation, 536).

43 E.g. Manville 1994; Connor 1994, 40-1.

44 See Duplouy 2002 for a general review of the literature. The title of this section obviously refers to Davies 1981.
} 
so-called 'Bücher-Meyer Controversy' or its development through twentiethcentury historiography, the so-called 'New Orthodoxy' of Finley and his followers. ${ }^{45}$ Suffice it to say that in recent decades, in a post-Finley era, scholars have tended to adopt a less theoretical and more contextual approach to the ancient economy, going back to the analysis of ancient texts and inscriptions. Following Anthony Snodgrass, they also rely more and more on archaeology to increase the amount of quantitative and qualitative information. ${ }^{46}$

Ancient sources particularly insisted on what is probably the sole unequivocal link between economy and citizen status: everywhere in Greece citizens were deeply attached to their lands. The link between landed property and citizen status is nowhere more obvious than in moments of forced exile: in 546, 'while they prepared to sail to Cyrnus, more than half [of the Phocaeans] were overcome with longing and pitiful sorrow for the city and the life of their land, and they broke their oath and sailed back to Phocaea' (Hdt. 1.165.3) and in 431 'deep was the trouble and discontent [of the Athenians] at abandoning their houses and the hereditary temples of the ancient constitution, and at having to change their habits of life and to bid farewell to what each regarded as his native city' (Thuc. 2.16.2). To acquire and own land and houses (enktēsis gès kai oikias) was indeed, as explicitly mentioned in various classical texts and inscriptions, a citizen privilege. As attested from the end of the fifth century, this privilege could also be granted to foreigners. But it always remained an exception and a great favour of the city to its benefactors, a fact that clearly reinforces the connection within all the citizen domains. As Jan Pečírka stated it for Athens, 'the services rendered by persons granted enktēsis took the form of help given to Athenians abroad, as well as services to Athens in the diplomatic, financial, military, supply, cultural, health (a doctor in $I G \mathrm{II}^{2}$ 373) and political spheres'. ${ }^{47}$ Such a link with the fatherland and its fruits is also emphasized in the Athenian ephebic oath, quoted by Lycurgus (1.77) and recorded in a famous fourth-century inscription found in 1932 at Acharnae: ephebes swore on various deities and on 'wheat, barley, vines, olive-trees, figtrees'. As has been regularly suggested, the text may be a reliable copy of an archaic civic oath despite the non-existence of the institutional ephèbeia before the fourth century. ${ }^{48}$ In classical Athens landowning was undoubtedly at the core of a citizen's self-definition and identification.

Similar ties between landowners and citizens might be claimed for archaic Greece. As emphasized by Henri Van Effenterre and Françoise Ruzé, such a

45 For a review of economic literature and particularly Finley's influential work, see Morris 1999a.

46 On the importance of material culture in research today, see e.g. Morris 2007; Dietler 2007; Osborne 2007.

${ }_{47}$ Pečírka 1966, 148-9. See also Gauthier 1976, 223-5. More recently Hennig 1994, esp. 305-36.

${ }^{48}$ Siewert 1977. 
privilege was mentioned or alluded to in a few (late) archaic inscriptions. ${ }^{49}$ In the early fifth century, the whole city of Gortyn awarded Dionysios various citizen privileges in acknowledgement of his bravery in war and his benevolence; notably, he received 'a house in Avlon inside the fortress and a plot

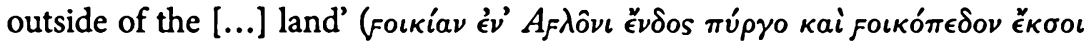
$\gamma \hat{a} \nu \kappa[-])$ (Nomima I, no. 8). At the same time a Gortynian law alludes to fields in Keskora and Pala allocated by the polis to be planted ( $\tau \dot{\alpha} \nu \dot{\epsilon}[\nu]$

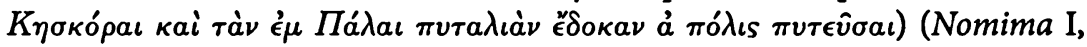
no. 47). Around 475 in Elis Deucalion is granted a piece of land in Pisa among other privileges making him a citizen equal to various officials of the Khaladrians ( $\tau \dot{\alpha} \nu \gamma \hat{\alpha} \nu \tilde{\epsilon} \chi \epsilon \nu \tau \dot{\alpha} \nu ~ \epsilon ̉ \nu ~ \Pi i ́ \sigma a \iota)$ (Nomima I, no. 21). The Pappadakis bronze plaque (Nomima I, no. 44) of the last quarter of the sixth century, said to come from the area of Naupaktos and dealing with a settlement in the western end of

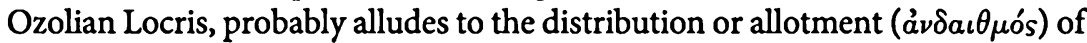
an area called 'the plain of Hylia and Liskaria' which had already been divided

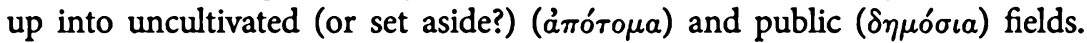
Despite doubts on the precise meaning of various terms, this archaic law written boustrophedon establishes a secure link between settlers and public land. Fragments of an archaic civic oath sworn by young Drerians for the defence

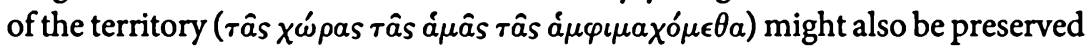
on a pillar of the late third century (Nomima I, no. 48). Lastly, landowning was undoubtedly a key factor in the Solonian property classes, not only because the name of the top class (pentakosiomedimnoi) unquestionably implies the possession of agricultural produce, but also because the Solonian census was reportedly assessed in terms of annual income in grain for all four classes (although it might also have been a later invention). As Lin Foxhall writes, 'membership of the elite group which constituted the state was synonymous with the land-holding group. ${ }^{50}$ As well as a means of maintaining one's family, landowning was also a means to assert one's citizen status in archaic Greece. In sum, in a society in which wealth was primarily land-based, landowning was an inescapable sign of citizenship, not to say a right to citizenship.

Is it possible to substantiate this on the ground? In the last four decades, archaeology has produced ample evidence for regular division of both rural and urban territory, mainly (but not exclusively) in Greek settlements abroad, in the Western Mediterranean and the Black Sea. ${ }^{51}$ Division into lots and urban planning are sometimes attested as early as the late seventh century. They have been long accepted as the sign of an early political consciousness, probably linked to some notion of citizenship as a right to a share of the citizen territory in town as well as in the countryside. According to David Asheri,

19 Van Effenterre and Ruzé 1994, 168-9.

50 Foxhall 1997 (quotation, 129); see also, in general, Zurbach 2017.

51 Boyd and Jameson 1981; Di Vita 1990; Müller 2010, 125-51. 
urban and rural land division is unmistakably revealing of egalitarian structures because it physically marks on the ground the 'rules of formal equality' (isomoiria). ${ }^{52}$ Mapping citizen equality onto the archaic landscape, however, is perhaps not to be associated automatically with democratic ideals or their possible precursors in archaic Greece-one might think of Ian Morris' 'strong principle of equality', although he does not specifically allude to land division in his model of a 'middling ideology'. ${ }^{53}$ As Michel Gras and Henri Tréziny note about the urban grid of Megara Hyblaea, 'Dans une société archaïque, aristocratique, fondée sur des solidarités et des hiérarchies entre des groupes et à l'intérieur de ces groupes, la définition de lots individuels égaux peut sembler paradoxale. Il est probable que ces lots sont en fait regroupés en entités plus vastes, en "groupes de lots" qui reflètent une réalité sociale. ${ }^{54}$ Symbolically much more meaningful than the allotment of unequal properties, another way to mark on the ground the patently unequal society of archaic Greece might indeed have been to allot unequally equal pieces of land! It is therefore questionable whether the fifth-century grid of Metapontum was linked, as initially proposed by Joseph Carter, to a political revolution in which tyranny was overthrown and a democracy established. ${ }^{55}$ Moreover, recent archaeological researches have revealed that the division lines in the landscape of the chora of Metapontum, a much debated subject for decades, were not necessarily related to land allotment, as has been repeatedly asserted, but were actually related-more pragmatically - to geomorphological facts and drainage techniques of rural lands. ${ }^{56}$ The numerous parallel Metapontine ditches reflect, first of all, local terrain morphology and drainage problems, rather than a centrally planned political land-division system. In sum, even if a landed approach to citizenship definition is consistent with the idea of a predominantly agricultural character of the economy and society of archaic Greece, regular land division does not actually say much about property principles or enfranchisement.

The relation between landowning and citizenship has often been described as exclusive. Convinced that land was the most important part of the ancient economy, Moses Finley elaborated a core link between agriculture and citizen status by stressing the juridical contrast between citizens and non-citizens. 'For the study of the Greek economy', wrote Finley, ${ }^{57}$ 'the distinction of the most far-reaching significance [...] was between the citizen and the noncitizen, because it was a universal rule-I know of no exception-that the ownership of land was an exclusive prerogative of citizens.' The citizen status

\footnotetext{
52 Asheri 1966, esp. 13-16; 1975.

53 Morris 1996. See below (section 5) for further discussion.

54 Gras, Tréziny, and Broise 2004, 546. $\quad 55$ Carter 1990.

56 Carter 2006; Carter and Prieto 2011.

57 Finley 1999, 48. Also see Austin and Vidal-Naquet 1972, 111-12.
} 
consequently erected a 'wall between the land and liquid capital' that was 'an impediment in the economy'. Beyond an ideological bias towards a primitivist approach to the ancient economy, Finley firmly justified the unbreakable link between citizen status and landowning, presenting it as 'the product of a juridically defined and enforced social hierarchy'. Finley devoted much of his thought to arguing that the ancient economy was a dimension of (legal) status relations rather than a separate sphere of life. Since the nature of economic activity was essentially determined by juridical and political situations, he disqualified citizens from any economic agency beyond the possession of land and the practice of agriculture. In a way, Finley's approach to economic activity was only a by-product of a legal approach to citizenship, which postulates a sharp distinction between citizens and non-citizens.

Besides a strictly primitivist approach, the real issue is to decide whether or not archaic citizenship was restricted solely to landowners. Was there a qualification for citizenship related to an assessable landowning, therefore prohibiting the landless from being citizens in archaic Greece? There are few clear-cut cases and, although the exclusion of the landless seems archaic (or archaistic) in its intent, these are mainly documented by classical authors. According to Aristotle (Pol. 2.1271a35-7 and 2.1272a15), Spartans whose landholdings were unable to produce the required monthly contributions to the common messes risked losing their citizenship. On the other hand, when, after the fall of the Thirty and the restoration of the Athenian democracy in 403, one Phormisios proposed that only landowners should have the franchise-a measure which, according to Dionysius of Halicarnassus (Lys. $32-3$ ), would have excluded up to five thousand citizens-the assembly rejected the proposal and consequently refused to limit citizenship to landowners. Was it too conservative or too revolutionary for the Athenian democrats? The only certain conclusion is that in classical Athens the possession of landed property was obviously not a prerequisite for citizenship, although some critics of democracy might have been tempted by the idea. There is no such agreement for archaic Athens.

For example, what kind of citizenship was enjoyed by the thetes of the fourth Solonian class, who were admitted to membership of the assembly and law courts but excluded from all public offices (Ath. Pol. 7.3)? If the author of the Constitution of the Athenians granted them less than a 200-medimnoi income in farm products-which might imply that some of them, at least, were small landowners-there have been doubts on the historicity of such an economic evaluation, and cases have been made in favour of a later rationalization if not invention. ${ }^{58}$ Similarly, could we ascertain that the hektemoroi were enfranchised? Although under permanent threat of enslavement for

58 Mossé 1979a; Raaflaub 2006a; Duplouy 2014. 
non-repayment of their debts according to the law of obligations of preSolonian time, they were nevertheless free tenants, as it seems, who cultivated other men's land in exchange for one-sixth (or five-sixths?) of the harvest (Ath. Pol. 2.2; Plut. Sol. 13.4-6). Accordingly, they formed a class of dependent peasants bound to work the fields of the landowners, but it is unknown if this economic divide could be equated with a citizen distinction. Both hektemoroi and the tes have been repeatedly assimilated to underprivileged citizens. However, as already discussed, such an idea of a partial citizenship, conceptualized by fourth-century political thought and elaborated by nineteenth-century German historiography, might be irrelevant to a genuinely archaic citizen concept. Adopting a critical approach to fourth-century historiography and towards an actual group of hektemmoroi, Tadashi Ito has indeed argued in favour of an invention related to the usual fourth-century interest rates, equivalent to one-sixth of the total loan, which would have been projected back into pre-Solonian Athens. ${ }^{59}$ Similarly, considering the general aporia of previous interpretations, Misha Meier has most recently argued for a complete reappraisal of the Athenian hektemmoroi. Considering that they are inconsistent with any plausible picture of pre-Solonian Athens, he postulates an error of fourth-century writers, who would have concatenated into a single expression the two words $\kappa \tau \hat{\eta} \mu a$ and oo of a few Solonian verses that are now missing. Although such sophisticated explanations are usually unsatisfactory, Meier maintains 'daß in Athen zu keinem Zeitpunkt eine gesellschaftliche Gruppe mit der Bezeichnung "Hektemoroi" existiert hat' and concludes 'Bei den Hektemoroi handelt es sich demnach-so die These-keineswegs um eine Gruppe unterprivilegierter athenischer Bauern oder Schuldner, sondern um eine versehentliche Erfindung. ${ }^{160}$ Whatever the exact meaning of both thètes and hektēmoroi, their relation to citizen status is far from clear and no definitive case has been made that poor landless men could be enfranchised in archaic Athens. Does this mean that having a share in citizenship was strictly entangled with landownership from the start?

Rejecting the idea of a legal gradation within the citizen status, Benedetto Bravo offered another interesting case study with the Syracusan gamoroi. Usually defined as a landed nobility or as an aristocratic subgroup within the whole citizen body, the Syracusan gamoroi are typically assimilated to full citizens as opposed to underprivileged Syracusan groups. ${ }^{61}$ According to Bravo, in early fifth-century Syracuse the gamoroi, as descending from the first colonists, were the only citizens. They formed the whole-although restricted-citizen body, which excluded both slaves and a large majority of free non-citizens. The latter were in no way underprivileged citizens excluded

59 Ito 2004. $\quad{ }^{60}$ Meier 2012 (quotation, 29).

61 Boerner 1910. Still described as a 'ruling aristocracy' by Gehrke 1998 and Lomas 2013. 
from various political or judicial rights, but men to whom citizenship was purely and simply denied, assimilating them to mere foreign residents. ${ }^{62}$ If a general rule has to be postulated for archaic Greece, Bravo proposes to rule out dependent peasants completely from any citizen status, instead of granting them an anachronistic underprivileged legal status shaped by fourth-century political thought. ${ }^{63}$ In most-although probably not all-archaic cities dependent peasants in his view formed the majority of the non-privileged (i.e. non-citizen) component of a city's population. These people, standing between citizens and slaves within the social spectrum, were free peasants lacking or having not enough land property to buy the hoplite panoply. To earn their living, they had to sell their own labour to rich landowners. Taking advantage of Aristotle's own inconsistency, Bravo in particular argues that the Athenian thètes were in such a condition.

To take care of one's land and to safely transfer it to one's heirs was undoubtedly a security against the loss of citizen status over time. Despite the general rule of inalienability of land, this barrier was permeable: besides the possibility of purchase of real estates, already mentioned in Hesiod (Op. 341), the recurring division of inherited land over the generations and the consequent impoverishment of successive landowners would have made easier the various processes of property confiscation by creditors. In sum, if the close link between the ownership of land and citizen status did not necessarily preclude the landless from enjoying citizenship in democratic Athens, it could have been the case in earlier Greek societies in which wealth was primarily land-based.

However, since 'money makes the man' according to Alcaeus (fr. 360 Voigt), it is worth considering how the economic dimension of citizen status could also possibly extend to other fields of economic activity. This is the topic of another long-standing controversy, both modern and ancient, on the relationship between the sources of incomes on the one hand and civic, political, and juridical rights on the other.

A citizen disqualification for manual workers-except for farmers-is indeed deeply rooted in ancient political thought. In a Socratic dialogue, Xenophon has Socrates saying in some states, especially those reputed to be warlike, no citizen is allowed to exercise any handicraft at all' (Oec. 4.3). In his ideal state, Plato (Leg. 8.848A) would set apart craftsmen, foreigners, and resident aliens from citizens and slaves. More radically, Aristotle recommends excluding all those who work for a living from membership in his ideal city or any real city, and he forbids his citizens from doing such work. Having no practice of virtue (see above, section 1, for the Aristotelian discussion on the value of a good man) craftsmen are belittled as 'banausoi' (the 'vulgar') and

62 Bravo $1992 . \quad 63$ Bravo 1996. 
naturally excluded from citizenship or at least from those capable of governing (the rulers, archontes politai), that is, from all public offices if not from the assembly. If workers are to be enfranchised, they can be nothing else than ruled citizens (archomenoi politai). In arguing thus, Aristotle sets forward various examples of aristocratic cities: 'At Thebes there was a law that no one who had not kept out of trade for the last ten years might be admitted to office' (Pol. 3.1278a25-6), while in Thessaly 'no artisan or farmer or any other such person may intrude' into the agora used for the meeting of the assembly (Pol. 7.1331a32-5).

This ancient political prejudice against manual workers was further developed by modern historians and notably by a 'substantivist' approach to the ancient economy. It is well known that, besides the ongoing primitivistmodernist controversy, Max Weber contributed to diverting the economic debate by insisting on an essential distinction that characterized the long-term history of the whole Western world: 'The political situation of the medieval townsman determined his path, which was that of a homo oeconomicus, whereas in Antiquity the polis preserved during its heyday its character as the technically most advanced military association: the ancient townsman was a homo politicus. ${ }^{34}$ Since man was by nature, according to Aristotle (Pol. 1.1253a3), a 'political animal' (politikon zōon), a creature meant to live a political life, the Greeks did not devote their lives to making money. Such an economic bias promoted by ancient political thought was accepted by Weber. Greeks were not supposed to be primarily driven by economic gain, whereas modern capitalism is built on that core principle. Johannes Hasebroek further elaborated this distinction between the ancient homo politicus and the modern homo oeconomicus, progressively leading-with Karl Polanyi and Moses I. Finley-to a 'substantivist' approach to the ancient economy. ${ }^{65} \mathrm{In}$ ancient Greece the economy was therefore 'embedded' in society: not only was there a close relationship between economy and status, but economic activity was conditioned by the status of economic players too. No traders, merchants, or craftsmen could ever be accepted as 'true' citizens. Conversely, no citizen could be involved in a purportedly demeaning or vile activity such as trade and industry, which were expelled beyond the realm of the city. According to Hasebroek, trading activity and manufacture were mainly in the hands of foreigners, whereas the citizens were above all landowners. In short, the economy was status-driven: traders and craftsmen could only originate from the lowest social, political, and economic plane.

The 'substantivist' approach to the ancient economy therefore insisted on socially embedded economic exchanges, supposedly more appropriate to a citizen condition. Finley himself contributed to minimizing the role of the

64 Weber 1978, 1354. See also Humphreys 1978 b.

65 Hasebroek 1928; 1931. On Karl Polanyi, Humphreys 1978a; Clancier et al. 2005. 
market in ancient Greece, insisting on non-mercantile modes of economic exchange. Gift-giving and reciprocity were key concepts of Polanyi's analysis of primitive economy that Finley set at the core of his thought as early as 1954 with the World of Odysseus. In an extensive subsequent literature, reciprocity was recognized as a major tool in social agency, not only in the Homeric world but also in archaic and classical cities, allowing people to be ranked among their peers or even within the whole spectrum of society. ${ }^{66}$ Although it has never been properly identified as a criterion of citizenship or as a prerogative of citizens alone, gift-giving (and the whole set of reciprocity behaviours) became a major reason in classical and Hellenistic Greece for publicly honouring foreigners or even granting them citizen rights. In early fourth-century Athens the former slave Pasion, the famous bank and factory owner, was granted citizen rights, and notably the gès enktessis. The favour was not related to the huge assets (more than 60 talents) he accumulated during his lifetime nor to his vigorous entrepreneurial activity, but 'on account of services to the state' ( $\delta \iota \dot{a} \tau \dot{a} s \epsilon \dot{v} \epsilon \rho \gamma \epsilon \sigma i a s ~ \tau \dot{a} s \epsilon i s \tau \dot{\eta} \nu \pi o ́ \lambda \iota v$ ) and notably for the gift (epidosis) of a thousand shields to the city. ${ }^{67}$ The same might be said for other rich and liberal metics such as Lysias' father (though never granted citizenship) or Phormion, who initiated his career as Pasion's bought slave. Beyond the grant of the honorary title of euergetes, which implied various commitments between 'partners', classical and Hellenistic Greek poleis could indeed honour foreign benefactors and their descendants with formal citizenship. In short, euergesia as part of a pattern of reciprocity was by nature an expected behaviour of candidates for enfranchisement. In archaic Greece too, as Nick Fisher demonstrates in this volume (chapter 8), various cities granted citizen rights to foreign award-winning athletes who became a credit to their new homeland.

Despite the ancient and 'substantivist' prejudice against trade or handicraft, many traders or craftsmen were in fact enfranchised in ancient Greek cities. Bridging the gap between theoretical approaches to the ancient economy and the analysis of sources leading to establishing facts, Alain Bresson contributed to the challenge to Finley's 'New Orthodoxy' and the assumption that Greek poleis took little interest in commerce. ${ }^{68}$ Although accepting the basic idea that all kinds of economic exchanges are embedded in social life, Bresson forges the contrasting idea of a 'merchant city' and brings back into favour for ancient Greece the concept of a market economy. Focusing on prosodoi, he attempts to locate the main purpose of the ancient economy in the idea of managing revenues and expenditures, in both private and public life. In reviewing his work, Edward Harris notes: 'Br. traces the role of the ancient state in the

66 See especially Veyne 1976; Finley 1983, 24-49; Gauthier 1985.

67 Dem. 45.85; 59.2; cf. Davies 1971, 427-35 (no. 11672).

68 Bresson 2000; cf. Harris 2001. 
economy back to the Iliad: the original form of the economy was to raid for plunder and distribute the booty to soldiers. This practice did not die out with the development of the polis but remained firmly in place: war for profit remained a central feature of the polis' and 'when there was no booty from war, the polis might distribute profits gained from mines or other public revenues'. In sum, 'To be a citizen was to belong to a club that paid dividends'- 'un club distribuant des dividendes' ${ }^{69}$ According to Bresson, the role of a city's economy was to create profits and to distribute them among the members of the club or to make use of them to pay for community expenses (army, festivals, public and religious architecture, etc.). In contrast to a primitivist view, Bresson shows how Greek cities could play a part in regulating the economy by setting 'official' wholesale prices on the grain market or controlling retail prices. He demonstrates how cities, while securing a steady supply of imports by concluding treaties with foreign poleis or kings, also promoted exports. Cities founded their much sought-after autarkeia not on self-sufficiency but on regulating imports and exports. In short, Bresson demonstrates that the Greek poleis had no aversion to commerce and took an active interest in regulating trade. Right from the archaic period cities also favoured a culture of competition among elites that could benefit the whole community. He shows, for instance, how rich merchants were members of the elite or acted as officials in public institutions. Ancient citizens might definitely be traders.

This is perfectly clear for classical Athens. Arguing against the idea of a democracy primarily made by and for leisured landlord citizens, Saber Mansouri stresses how deeply the 'working class' of classical Athens was similarly embedded in politics and active citizenship. ${ }^{70}$ Part of the citizenry in fourth-century Athens consisted of shopkeepers, merchants, and small craftsmen, whose involvement in politics was no small business at all. Although the (trade) agora was not an institutional place for decision-making, public debates and political strife initiated within the assembly or the citizen courts went on openly in perfumers', butchers', barbers', shoemakers', or tanners' shops, spreading the news, establishing or destroying men's reputations and bringing about changes in public opinion. Well beyond the usual examples of Nicias, Cleon, Demosthenes, or Apollodoros, many citizens or even officials of classical Athens, while involved in public life or in the service of the state, were also owners of small factories and workshops or even hired out slaves to the lessees of the mines. Mansouri's book reminds us that history is more complicated-and certainly more interesting for a historian of archaic citizenship-than the moral ideal of a few ancient philosophers such as Plato and Aristotle or the economic irrationality of 'substantivists'. If there is 
considerable prosopographical evidence within the Attic orators and the Inscriptiones Graecae to offer a well-documented and balanced account of the relationship between citizenship and economy in classical Athens, there are not as many sources for archaic Greece. At least, pre-classical authors were not (necessarily) as biased against manual work as Plato and Aristotle. ${ }^{71}$ Advising his brother to farm his land, Hesiod claimed: 'Work is no disgrace: it is idleness which is a disgrace. But if you work, the idle will soon envy you as you grow rich, for fame and renown attend on wealth' (Op. 311-13). Hesiod's Work and Days as a whole is indeed an exhortation to 'toil at toil after toil' (382). And beyond farming, other activities were acceptable as well for the poet, even trading overseas as his father did (Op. 633-40).

Maritime trade was precisely the topic of a famous controversy between Alfonso Mele and Benedetto Bravo. ${ }^{72}$ Although both had in common Hasebroek's and Polanyi's theoretical framework, they disagreed on the nature and details of overseas trading activity. Mele distinguishes between two consecutive types of archaic trade, prexxis and emporie. The former was an occupation among many of the landed elite; it was a non-specialized seasonal trading activity set in connection with fieldwork and embedded in a context of aristocratic guest-friendship deeply rooted in the Homeric world. The latter, which began during the seventh and sixth centuries, was a profit-oriented commerce in the hands of professional traders that was accordingly much less socially acceptable. Impoverished aristocrats or kakoi of one kind and another who engaged in such a specialized activity eventually formed a new middle class primarily driven by wealth. According to Bravo, on the contrary, those who travelled the seas to sell and buy abroad agricultural surplus and manufactured goods were mainly men who stood in a relation of belonging or personal dependence to the rich landowners. They were slaves or dependants of the nobles. Some of these traders, such as the Aeginetan Sostratos or the Samian Colaios, might even be impoverished nobles tempted by the spirit of adventure or constrained by poverty. In short, despite taking the risk of resurrecting the commercial aristocracies and merchant middle classes popularized by nineteenth-century modernizers, Bravo and Mele agree on what is at stake here: contrary to the position of Hasebroek who excessively assigned all trade to foreigners, there is no doubt that in archaic Greece, citizens, more or less propertied, were actually involved directly or indirectly in maritime trade. Furthermore, they also concur in the idea that a trader's social status was in no way primarily defined-even if it was subsequently corrupted-by his economic activity, a reservation that is of course attributable to a Finleyan conception of the relation between trade and politics in ancient Greece.

71 Descat 1986.

72 Bravo 1974; 1977; 1984. Mele 1979; 1986. On that controversy, Cartledge 1983, esp. 7-10; Reed 2003, 62-74. 
However, as has been argued subsequently, in spite of a reputedly base activity, a trader such as the Samian Colaios could perfectly well be praised thanks to related achievements such as paying a tithe on his huge profit, dedicating a magnificent offering to the gods, or favouring public interstate policy through private connections. ${ }^{73}$ Many scholars therefore agree, as JohnPaul Wilson states, in rejecting Finley's belief in 'a status-driven economy, where decisions were taken not on economic criteria, but on how they would affect the social/political standing of the decision-maker. ${ }^{74}$ As shown by various late archaic documents (including the three lead letters from Berezan, Olbia, and Emporio, as well as the famous Pech-Maho lead), archaic trade was much more sophisticated than used to be thought, implying well-organized and wealthy businessmen, highly involved in their agents' activities and keeping detailed records of their transactions. Although there is now no doubt on their economic and social standing, the ultimate proof of their citizen status is still lacking. However, the likely author of the Pech-Maho document, probably a business contract, was a certain ' $H \rho \omega \nu$ oi rather a letter-sequence that might be better understood, according to John Chadwick, ${ }^{75}$ as ${ }^{~} H \rho \omega \nu{ }^{\prime}$ " "Ioos. If we accept the otherwise unattested "Ilos as a variant of the usual ethnic 'I $\eta^{\prime} \eta \bar{s}$, this Heron could be a citizen of Ios. Whatever the actual political status of this man, the debate at least shows that scholars are now less reluctant than ever to accept a citizen qualification for archaic traders or other manual workers. Without excluding politics from the debate on trade and industry, recent critics of Finley's orthodoxy simply acknowledge the fact that in archaic Greece the citizen elites sometimes got their hands dirty with investments in trade, lending, and handicrafts.

If modern approaches to the ancient economy have long been flawed by fourth-century prejudices against manual workers, scholars are also rediscovering archaic poetry with a different outlook. According to Hans van Wees, 'archaic poetry leaves no doubt that a powerful acquisitive drive, rather than a struggle for mere self-sufficiency, shaped the archaic economy. ${ }^{76}$ As we know, throughout the archaic period and across the whole social spectrum, individuals were engaged, for the sake of forging or consolidating one's status, in an escalating competitive display of wealth through the consumption of imported commodities and a series of money- and time-consuming performances that I called 'modes de reconnaissance sociale' in a study on how elites were defined in archaic Greece. ${ }^{77}$ There is no doubt that this struggle for social standing boosted the economy of the archaic world. In every single field of economic activity, whatever their political or social status, individuals tried

\footnotetext{
73 On Colaios' achievements, see Duplouy, Mariaud, and Polignac 2011, 300-3.

74 Wilson 1997-8 (quotation, 32). ${ }_{75}$ Chadwick 1990, esp. 166.

76 van Wees 2009 (quotation, 450).

77 Duplouy 2006a. See also Fisher and van Wees 2015b.
} 
hard to get wealthier. Competition for wealth was simply pervasive. Despite noble principles of generosity and redistribution that indeed governed numerous demeanours in archaic Greece, Alcaeus' lament 'money makes the man' (fr. 360) does not imply at all that the archaic world as a whole rejected profit making. On the contrary, increasing one's property was a by-product of competition for status, as well most probably as a driving force behind social and political aspirations in archaic cities. 'Get rich or die trying' might have been quite a usual motto for enterprising people, especially if this wealth enabled them to acquire the hoplite equipment.

In sum, if landowning was certainly an obvious sign of citizen status in archaic Greece, an ultimate criterion of enfranchisement might be simply wealth, whatever its origin, landed, industrial, or commercial. In contrast to the conservative political thought of classical authors, debarring traders or craftsmen from citizenship might ultimately look like an anomaly rather than the common rule. In archaic Greece, propertied men were undoubtedly citizens-and citizens were normally propertied men.

Often defined as a 'club of warriors', the Greek polis long maintained a strict association between military service and citizenship. Even if political rights were regularly allocated on the basis of property qualifications, enlistment in the citizen army may have been a major criterion for enfranchisement in archaic Greece. According to Aristotle's reconstruction of the past, 'the earliest form of constitution among the Greeks after the kingships consisted of those who were actually soldiers, the original form consisting of the cavalry [...] but as the states grew and the wearers of heavy armour ( $\tau \hat{\omega} \nu \dot{\epsilon} \nu \tau o i{ }^{\circ}$ ö $\left.\pi \lambda \circ \iota_{s}\right)$ had become stronger, more persons came to have a part in the government' (Pol. 4.1297b16-24). Listing the various social components of a state, Aristotle

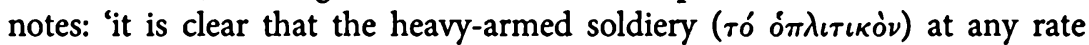
must be a part of the state' (Pol. 4.1291a32-3). As the author of the Constitution of the Athenians (4.2) records for the time of Draco, "citizenship had already been bestowed on those who provided themselves with arms (rois ö $\left.\pi \lambda a \pi a \rho \in \chi o \mu \epsilon^{\prime} v o(s)\right)^{\prime}$. The expression hopla parechesthai appears as early as the late sixth century. It is used in the earliest Athenian decree to survive, related to the status and obligations of the Athenian cleruchs living on Salamis, where it appears that the cleruchs must provide their own arms to the value of thirty drachmas (IG $\left.I^{3} 1.9\right)$. Even though the constitution of Draco has long been challenged as a forgery emanating from the oligarchy of 411 , the idea of including among citizens those able to provide their own arms might have been archaic in tone. As a member of the city, the citizen must contribute, as a duty and an honour, to the defence of the community. Archaic poetry is full of exhortations to die for the fatherland (Tyrtaeus, Callinus, etc.) and among the earliest occurrences of the word politai, in the Iliad, some of them refer to the troops (Il. 2.806, 15.558). Contributing to the defence of the polis by enlistment in the citizen army meant having enough personal resources to acquire 
the hoplite panoply. Military obligations were thus inevitably linked to an economic capacity, excluding less well-off men from being a citizen-soldier, but not necessarily forbidding them to contribute to the defence of the state. According to Aristotle, indeed, oligarchic constitutions usually hold that 'the poor are allowed not to own arms (hopla), but the well-to-do are liable to a fine if they have not got them' (Pol. 4.1297a30-2). What does that mean? If it was a duty of the propertied men to contribute to the citizen army, the poor were not formally excluded from enlistment. They were allowed to own weapons, and would have done so if they were able to afford hoplite arms and armour, so that the criterion for enrolment in the 'club of warriors' was ultimately economic. ${ }^{78}$

The link between war and society and, more specifically, between war and economy has been at the core of recent literature on warfare in Antiquity. ${ }^{79}$ As the main source of income, land property is firmly associated once again with the discharge of military obligations. The strict homology between warfare and landowning is indeed well established in ancient thought-according to Aristotle (Pol. 4.1291a30-1), "it often happens for the same men to be both hoplites and farmers'-and in modern historiography. Using the Homeric metaphor of weaving, Michel Gras and Henri Tréziny further associate 'rangées de lot' and 'rangées d'hoplites' in the construction of the polis of Megara Hyblaea through its city plan: 'à la hiérarchisation des éléments constitutifs de l'armée répond une hiérarchisation des espaces de la cité. L'hoplite dans son armure tient son rang comme le citoyen dans son lot' and further 'Il y a donc entre la cité et la phalange, une relation structurelle forte' making it archaeologically detectable in the polis territory ${ }^{80}$ The case is also obvious for Sparta. Young Spartans were educated according to a military organization and their adult social life continued to be organized in messgroups clearly related to military units. The Spartans were supposed to contribute to the organization of the common mess and, according to Aristotle (Pol. 2.1271a35-7; 1272a13-15), those who were unable to pay this tax ceased to belong to the 'club'. To ensure access to public messes, Spartans developed various institutions (such as the attribution of a klëros) and subjected entire populations (such as the Messenian helots) to provide a minimum land income to all citizens. Despite its peculiarities, however, the Spartan system was not fundamentally different from those of other Greek states. Property qualifications have also been recurrently interpreted as military structures, therefore defining the citizen-soldier in terms of agricultural production. To be specific,

78 Note the mistranslation of these lines by H. Rackham in the Loeb edition (1932)-'the poor are not allowed to possess arms'-as often pinpointed by van Wees (2001, 59 and n. 73; 2002, 62; 2006b, 371-2 and n. 81; this volume (chapter 4, section 1)).

79 Garlan 1989; Rich and Shipley 1993; Cartledge 1996c; van Wees 2007.

80 Gras, Tréziny, and Broise 2004, 563. See also the case of Thessaly treated by Helly 1995. 
the four census-classes (telē) reportedly created by Solon in early sixth-century Athens (Ath. Pol. 7.2-4, Arist. Pol. 2.1274a18-21, Plut. Sol. 18.1-2) have long received a military explanation. ${ }^{81}$ Although preferring a quantitative assessment of their farming capacity in the definition of the Solonian hippeis (an annual harvest of 300 medimnoi of barley), the author of the Constitution of the Athenians (7.4) already reports another explanation, the ability to breed a horse, which has been judged as a clear indication of the military origin of the Athenian 'equestrian class'. Similarly, zeugitai have been usually regarded as soldiers metaphorically 'yoked' together in the ranks of the hoplite phalanx, rather than-more literally-those who owned a pair of oxen under the yoke (zeugos).

If farmers must have regularly sold their products on the market to obtain the cash needed to buy military equipment, landowning might not have been an exclusive prerequisite for the inclusion in the citizen army of archaic poleis. As long as auto-equipment was the rule (hopla parechesthai), there were probably other means to acquire the financial capacity to buy hoplite arms and armour. According to Benedetto Bravo, 'naturalmente, nelle poleis arcaiche,

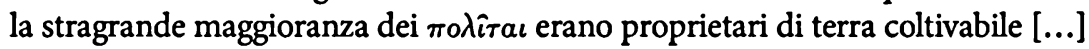
è probabile che in molte poleis anche i proprietari di prospere botteghe artigianali, essendo in grado di andare in guerra come opliti, godessero dei diritti civici' ${ }^{82}$ If classical armies included-though not all as hoplites-large numbers of resident aliens, serfs, and slaves with no right to own land, poleis had no intention of granting them citizen rights. ${ }^{83}$ Hence Hans van Wees could write: 'the experience of warfare thus did not in itself politicize social groups-but those who were politically active never failed to cite this experience in justification of their claims to power. ${ }^{84}$ This might not adequately apply, however, to archaic Greece, a time of elaboration and maturation of the citizen community. There was certainly, for example, an interest in military manpower in the large-scale forced population movements seemingly initiated by Sicilian tyrants and this undoubtedly had major impacts on the concept and granting of citizenship within Sicilian cities: according to Kathryn Lomas, Sicilian tyrants did not develop 'the very strong bonds between population, land and citizenship which was characteristic of the core areas of the Greek world'. ${ }^{85}$ Only the classical obsession with landowning to the exclusion of other honourable-i.e. citizen-compatible-economic activities seems to be an obstacle to the acceptance of a more economically open conception of citizenship, which conversely might have been more widely accepted in archaic Greece.

81 Since Cichorius 1894. See now Whitehead 1981; de Ste. Croix 2004a; Raaflaub 2006a. On the military assignments of the so-called 'Solonian classes', see also van Wees this volume (chapter 4).

${ }_{82}$ Bravo 1996, 537. ${ }_{83}$ See Hunt $1998 . \quad{ }_{84}$ van Wees 2007, 298.

85 On this topic, see most recently Lomas 2006 (quotation, 115). 
One wonders then if, in contrast to the status-driven economy once theorized by Moses Finley, archaic Greece might not have developed and promoted a kind of economy-driven citizenship or, at least, a form of citizenship partly elaborated on an economic capacity? In order to be a citizen and to be accepted as a citizen by other members of the community, one had to give proof of a sufficient financial capacity, notably by acquiring - no matter howthe required hoplite equipment to contribute to the protection of the citizen community. Unlike classical democratic Athens, which needed a large number of thètes serving as rowers in the navy, poor citizens had definitely no place in archaic cities....as long as they were unable to afford the arms and armour of the citizen-hoplite. Despite many possible social or political obstacles, the power of wealth was undoubtedly overwhelming.

\section{THE TERMINOLOGICAL APPROACH}

Beyond law, institutions, and economy, there are other ways to define archaic citizenship. Throughout the archaic and classical sources, the words denoting citizens may offer glimpses into the content of citizenship, while their changing use can provide clues about its evolution. There is a long tradition of research on the history of political terminology up to the recent formulation of the so-called lex Hafniensis de Civitate by Mogens $\mathrm{H}$. Hansen on the meaning of the word polis. ${ }^{86}$ Beyond the mere process of decision-making, numerous studies try to articulate the wide spectrum of meanings covered by ancient vocabulary, progressively leading scholars to assert a more sophisticated image of citizen societies. Through terminology an attempt can thus be made to analyse the concepts that the Greeks used to describe citizenship and its evolving content.

As Françoise Ruzé sets it, 'une première approche du citoyen en ses origines passe par la terminologie qu'emploient les textes archaïques ${ }^{37}{ }^{87}$ Initially, collective terms such as laoi and ethnics like Ithakesians or Trojans show that in early times citizens were deeply embedded in the community. In Homer 'les laoi constitueraient déjà ce que l'on pourrait appeler un "corps civique": l'ensemble des hommes libres de la communauté, tous groupes confondus et quelque [sic] soit leur niveau social, à l'exclusion du chef', writes Ruzé, whereas dèmos refers to 'l'ensemble de la population libre à l'exclusion du cercle des dirigeants. ${ }^{88}$ According to Ruzé, the individual citizen only emerges

${ }^{86}$ Welskopf 1981; Reinau 1981; Bordes 1982; Raaflaub 1985; Lévy 1985; Hansen 2000b; Osborne 2011, 92-102; Blok 2017, 146-86.

87 Ruzé 2003b (quotation, 166).

88 Ruzé 1997, 70. A slightly different view is exposed by Werlings 2010, with laos as 'un groupe d'hommes sous l'autorité d'un chef' (51-64) and dèmos as 'les habitants d'un territoire' (65-88). 
with astos and polites, two terms that stem from the words denoting the town or the city, astu and polis, which however were long deprived of any significant political content. In Homer politai sometimes applies to military troops (Il. 2.806), but more generally to the inhabitants of a town (Il. 15.558; Od. 7.131). By following the use and meaning of these words in archaic poetry and inscriptions, Ruzé proposes to identify the creation of an 'active citizenship' (or full citizenship) as a three-step process: first, a self-consciousness of belonging to a group that is distinct from foreigners; second, the acknowledgement of individual rights and guarantees within the community; and third, an enrichment of the content of citizenship that went with a gradual regulation of the enlargement of the citizen body. The terminological distinction between insiders and outsiders seems indeed to be at the core of an early definition of the citizen community. Hesiod (Op. 225) mentions xeinoi kai endèmoi, strangers and men of the land, as the two groups of people subject to the law. In archaic inscriptions, as well as in late sixth- and fifth-century poets, the formula astoi kai xenoi refers to all the men living on a territory, the

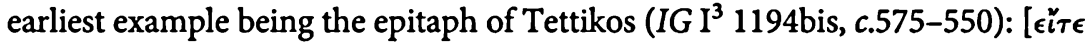

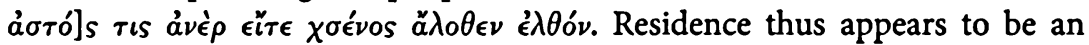
essential feature of early citizenship terminology. But if the expression factia

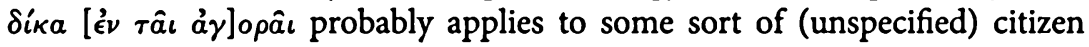
rights in late seventh-century Gortyn (Nomima I, no. 1), the word politēs and its Cretan antonym allopoliatas do not appear in epigraphy before the end of the sixth century. Meanwhile late archaic inscriptions clarify the content of this citizenship by mentioning various social and legal privileges. At this point lexicology meets Ruzé's legal approach, as previously described (see above, section 2).

Josine Blok has recently offered a slightly different treatment of the 'words used to designate the people who made up the polis', without a compulsory reference to the possession of political rights. ${ }^{89}$ Three sets of words were used to designate 'citizens': politai, astoi, and ethnika. Politēs in the singular does not occur in our texts until the last quarter of the fifth century, whereas the plural was equivalent in archaic texts to 'fellow-inhabitants of a city' without any obvious politico-legal overtones. Like politai, the more current astoi occurs almost exclusively in the plural until the second half of the fifth century and essentially pictures the inhabitants as a group, not as a sum of individuals. During the whole archaic period a citizen is indeed conceptualized as 'being related to other people or belonging to a group', not as 'being entitled to do' or 'having specific qualities', such as individual rights and duties. More clearly than Ruzé, she insists on the fact that the emphasis on the individual citizen is therefore not an archaic phenomenon, but only a classical evolution, probably 
a consequence of Pericles' citizenship law. From a terminological perspective, archaic citizenship therefore appears to be a matter of collective identity, much more than a question of individual status as the legal approach has long promoted it.

Josine Blok also draws two significant conclusions that entail a radical shift from previous scholarly literature. First, from epic to the middle of the fifth century, no "relation between the words used for "citizen" and the enjoyment of any political or other rights could be found' in any of the archaic references. Political decision-making in the strict sense was only one element of citizen life, and the overriding emphasis of the Copenhagen Polis Centre on the political nature of the polis embodied in institutions certainly does not exhaust the content of citizenship in archaic and early classical cities. The process of political, legal, and institutional formalization in the meaning of these words is actually a classical-if not an Aristotelian-phenomenon. Discussing the use and abuse of Aristotle, she shows that even in the mind of the Athenians of the classical period arche and krisis were simply not what citizenship was about. Aristotle actually provides a fundamental break with earlier conceptions and historical experiences. In a statement that has never been so explicitly formulated, Blok notes: 'Aristotle's definitions of citizenship, created in accordance with his political theory and logic, cannot be used as a yardstick to measure Greek citizenship backwards into its earlier history.' Instead, both archaic and classical words and texts often insist on religious matters. According to Blok, membership of the community is therefore normally defined in ancient Greek poleis by regulating who is to participate in sacrifice and on what conditions, in other words who will be a member of the covenant between the community and the gods, as captured in the formula meteinai or metechein tön hierōn kai tön hosiōn..$^{90}$ The second conclusion derives from the predominantly nonpolitical sense of archaic and classical words and contexts referring to citizenship. Whereas previous literature is convinced that archaic citizenship is a male-only status, considering woman and citizen as two incompatible categories, Blok shows that the occurrences of citizen words in epic poetry and classical texts apply to both men and women, whether jointly or separately. If the context makes clear in various cases that only men were meant, the plural politai sometimes refers specifically to women. In Homer women were usually included in the use of the word politai and sometimes especially designated by the plural: fetching water at the springhouse, as referred to in Od. 7.131 and 17.206, was specifically a woman's task in the Greek world. Whereas women were excluded from political affairs, it seems that their involvement in festivals was sufficient to allow them to be accepted as citizens, at least in the current vocabulary of classical Athenian authors. Despite the Aristotelian 
theorization, which had been repeatedly reproduced by modern historians, their inclusion in the citizen body was a reality for most Athenians of the classical period. By focusing on the political and legal aspects of citizenship Aristotle simply dismissed women from citizenship matters. Rather than revising or supplementing Aristotle, the whole historiography on ancient citizenship has preferred to negate women's inclusion in the citizen body, and $a$ fortiori in archaic cities. A linguistic and semantic investigation, as conducted by Blok, inevitably allows to women a place in citizenship matters. This terminological fact is also supported by the strong connection between citizenship and public cults, in which women fulfil numerous and irreplaceable functions. Male and female members of the community had thus far more in common than is usually assumed. If men had exclusive control over political and judicial matters, women's involvement in cults (alone or in association with men) was deeply rooted in the structure and life of the polis. Undeniably, in recent studies, defining archaic citizenship has become an issue related to men and women alike.

Beyond the words generically denoting the members of the polis, personal names can also allude to various characteristics of a citizen status. Onomastics are not only a matter of collecting all personal names occurring in Greek literature, inscriptions, papyri, coins, vases, and other objects: as an integral part of language, personal names are also a key to the understanding of numerous aspects of the ancient Greek city-state culture. From the Wörterbuch der griechischen Eignennamen of W. Pape, first published in 1842 and then revised and augmented by G.E. Benseler, to the ongoing Lexicon of Greek Personal Names compiled in Oxford since 1972, the historical value and significance of personal names have been widely documented in various fields of classical scholarship. ${ }^{11}$ Politics is one of them: there are (male) names such as Protagoras (First in the assembly), Anaxagoras (Lord of the assembly), Peisistratos (the One who convinces the army), Leiodes (the One who is pleasing to the laos), Leiokritos (Chosen by the laos), etc. More specifically, Friedrich Bechtel once distinguished a category of 'names related to society' (der Name knüpft an das Verhältnis zur Gesellschaft an): beyond a general conception of society with its related qualities (respectability, benevolence, etc.) and besides affiliation to a family, he pinpointed names alluding to a special position in society (Lebensstellung), particularly those using a 'technical expression' related to a constitutional rank (staatsrechtliche Stellung) or to an occupation (Beruf). ${ }^{92}$ The various domains here listed by Bechtelinstitutions, army, navy, cults and religious associations, trade, arts, and sports-outline an extensive conception of ancient society, even if he does not specify the realm of the polis. There is no doubt that, considering the

91 See for example Matthews and Hornblower 2000.

92 Bechtel 1917, 509-19. 
wide range of categories related to personal names and the holistic nature of the polis, onomastics can also be a key to the definition of citizenship, its evolving nature over time and varying content in space.

\section{THE VALUE OF MATERIAL CULTURE}

Undoubtedly material culture is a much more practical, immediate, and unmediated testimony for archaic Greece than the Aristotelian model. It can provide a very promising source of information on archaic history, politics, economy, and therefore citizenship, insofar as a direct link between material culture and citizenship can be established. During the last thirty years, archaeology and art history have been at the core of new theories that have provided a whole new insight into archaic citizenship. To a sceptical mind, material culture will remain unreliable and only a matter of interpretation. For archaeologists and art historians, however, it is a serious matter whose potential goes far beyond a mere taxonomy of forms and styles. Although sometimes disregarded as indemonstrable, new ideas deriving from the study of material culture can also give birth to new reflection on written sources: enlightened by archaeology, scholars can also return to texts with a more open mind.

Even if they have access to a whole new documentation, much larger than the meagre corpus of archaic texts, archaeologists are not always free from classical and textual models. There is, indeed, the strong temptation to assume that material culture naturally and smoothly fits into the historical framework delineated by ancient authors, who were supposedly better aware of archaic matters than contemporary scholars. In an essay published in 1984 dealing with Aristotle and the rise of the Greek polis, Nicolas Coldstream aimed at verifying Aristotle's theory on the formation of the polis by comparing it with archaeological discoveries. Stressing the fact that, by Aristotle's time, the polis had not yet taken root in many parts of Greece (especially in the backward regions of north-western Greece, cf. Thuc. 1.5-6), he accepts Aristotle's scheme on the genesis of the Greek polis and indeed praises his methodology: 'With such examples before his eyes, Aristotle could reconstruct the antecedents of the polis in the more progressive parts of the Greek world; just as today a social anthropologist, showing far greater boldness than Aristotle, may study the ways of primitive societies still existing in Africa and the Pacific islands, in the hope of throwing some light thereby on an early stage of an ancient civilisation. ${ }^{93}$ According to Coldstream, archaeologists could thus use Aristotle as an anthropologist of the ancient polis in order to read the material 
culture of early Greece, stressing how far, for example, 'the archaeological record is consistent with Aristotle's village theory. ${ }^{94}$ Unfortunately, this idea has often been applied uncritically to archaeological discoveries. For example, Nota Kourou recently associated the transformation of the small, mountainous Tenian community of Xobourgo into the main settlement of an archaic polis with the markedly Aristotelian idea of 'a shift from familial to communal cult'. ${ }^{95}$ I fear, however, that Aristotle's account of early Greece lacks any empirical basis and mainly rests on a philosophical construct.

State formation is nevertheless at the core of archaeological studies. As with other approaches to archaic citizenship, the birth of citizenship, defined as a membership of an emergent city-state, is often studied through the notion of the rise of the Greek polis. In his very stimulating and influential book Burial and Ancient Society (1987) Ian Morris proposed to investigate the birth of the polis through burial customs. According to Morris, since the citizen body is coextensive with the state itself-the citizens being the polis-the archaeological record should also reveal the genesis of the citizen status. From the early Dark Age to the mid-eighth century, 'formal burial' (i.e. an archaeologically visible tomb) was in many places restricted to a small group of privileged people. A major change occurred in the structure of funerary practices around 750, with a wide extension of the right to a 'formal burial'. According to Morris, this change corresponds to the invention of the idea of the polis and the attendant appearance of citizenship. Referring to the sociology of Vilfredo Pareto, Morris defines citizenship as 'the ideal form of relationship within the groups formerly separated as agathoi and kakoi, agathoi being those always represented in the archaeological record and kakoi those sometimes excluded. ${ }^{96}$ As Morris puts it, 'formal burial within spatially defined cemeteries was considered a primary symbol of the social group monopolising full membership of the community, through lineal descent from the dead'. ${ }^{97}$ In early cities a 'formal burial' was granted to all citizens, whereas non-citizens were excluded from such ritual. Both proposals, archaeologically invisible disposal for parts of the population and the link between formal burial and full membership of the community, were controversial ideas that often provoked opposition to Morris' thesis. Thirty years later they nevertheless remain the only viable hypothesis to deal with some of the major changes in the funerary archaeological record of the eighth century throughout Greece. The widening of the burial group within the general population and the attendant transformation of the political structure of the whole community are necessary aspects of any historical explanation of the sharp increase in the number of burials during that period. A mere demographic increase of the population, as formerly promoted by Anthony

94 Coldstream 1984, 15.

96 Morris 1987, 176-7.
95 Kourou 2008 (quotation, 84).

97 Morris 1987, 9. 
Snodgrass, ${ }^{98}$ cannot account for all aspects of this great transformation. Not to mention that a 3.1 per cent rate of annual growth of the population of Athens and Attica, as the drastic increase of grave numbers during the eighth century (MG II-LG II) would imply, is unlikely in any pre-modern society without improved sanitary conditions, developed health care, or intensified agriculture.

If there is undeniably a kernel of truth in Morris' theory and therefore a link between early citizenship and burial customs, this specific approach to the archaic Greek polis is certainly not without critics. By focusing exclusively on the funerary field, Morris simply forgot other essential aspects of community life, particularly cult activity. Early Iron Age Greece saw the emergence of a great diversity of local, regional, or interregional cults, which contributed to the definition of communities. This widespread phenomenon went together with the creation of specific categories of votive objects, such as bronze tripod cauldrons, and a transfer of goods from necropoleis to sanctuaries, two components of the same archaeological trend that prevents us from analysing burials separately from cults. This major objection led François de Polignac to propose an alternative model of early Greek polis formation. ${ }^{99}$ His approach, strongly influenced by French anthropological structuralism, favours a holistic view of the polis where religion and politics are intimately intertwined. As Oswyn Murray metaphorically describes it, referring to a long national tradition going back to Fustel de Coulanges, 'the French polis is a form of Holy Communion', whereas the German polis 'can only be described in a handbook of constitutional law'. ${ }^{100}$ Arguing against a strictly institutional approach to the Greek city, Polignac defines the emerging polis as 'a social entity founded upon a network of relations between the various members of a territorial community'. ${ }^{101}$ More precisely, by focusing on the function of the sanctuary in the society, he adds his own contribution to assimilating the Greek city-state to the 'formal expression of a religious cohesion'. There is of course a fundamental difference between the Weberian 'city as institution' of Mogens H. Hansen and the Durkheimian 'city as society' of François de Polignac, inevitably leading to two radically diverging conceptions of archaic citizenship. According to Polignac, the geographical placing of sanctuaries played a major part in establishing the concept of the city-state in Geometric Greece. Many rural cults were meeting points for the neighbouring communities,

98 Snodgrass 1977, 11-12; 1980, 22-4. And then, acknowledging Morris' observation, Snodgrass 1991, 16-17; 1993, 31-2.

${ }_{99}$ Polignac 1995a. See Polignac 1994 and 1996. For critics of Polignac's model, especially in the anglophone scholarship, see Irad Malkin's review in JHS 107 (1987), 227-8, as well as Hall 1995, and various papers in Alcock and Osborne 1994.

100 Murray 1990b, 3. On the multiple historical approaches to the polis, see also Azoulay and Ismard 2007.

101 Polignac 1995a, 78. 
offering many occasions for exchanging goods and for sharing commensality between participants in festivals, sacrifices, and ritual dinners. These sanctuaries, whether large rural sanctuaries on the edge of the plain or small cultplaces in mountainous or coastal areas, were at the centre of a regional or local network of settlements and appeared as focal points in the process of social and political mediation. Through cult activity, groups living in geographical proximity were progressively united into a single community, establishing a territorial solidarity among members of a new social and political entity. According to Polignac, 'the constitution of the polis is to be conceived not only in terms of access to the archai and participation in political citizenship, but also as the gathering of different groups into a single effective body by allowing them all access to the same cults, assembling them around a number of common sanctuaries, and granting all of them the privilege of taking part in certain rituals: in short, the polis has to be considered also in terms of a religious citizenship. ${ }^{102}$ Beyond the establishment of sovereignty within a given territory, the contemporary blossoming of heroic cults towards the end of the Geometric period shows how these communities also acquired self-awareness of themselves by assuming a sacred link with the past. Heroes were considered as common ancestors and strengthened the social cohesion of the whole community. Because they affected the entire social body, extraurban sanctuaries and cults of heroes created the city's religious space and helped define a common identity beyond any distinction in rank, sex, place, or means of living. 'Participation in religious rituals guaranteed a mutual recognition of statuses and set the seal upon membership of the society, thereby defining an early form of citizenship,' concludes Polignac. ${ }^{103}$ In this sense cults and their attendant rites of social integration should also be highly valued in the shaping of an early Greek citizenship. ${ }^{104}$

The same French anthropological tradition, often known (at least abroad) as the 'École de Paris', has produced other significant results in the field of citizen behaviours and their representations in visual arts. Two topics are of particular interest, the symposium and hunting, both of which had a major social role in the archaic period. Both behaviours are usually considered as typical expressions of an aristocratic lifestyle, but their political connotation and their implication in the definition of archaic citizenship should not be dismissed.

The introduction of the oriental habit of reclining on couches instead of sitting on chairs at the end of the Geometric period was a major

102 Polignac 1995a, 124-5.

103 Polignac 1995a, 153. See also, following Josine Blok's studies, van den Eijnde 2010, 28 ('A citizen is someone who has access to the shared set of rituals and symbols connected with that tier of identity that has the most political salience') and Wijma 2014.

${ }^{104}$ See my own development of the topic in Duplouy 2012a. 
transformation in Greek commensality. According to Jean-Marie Dentzer, ${ }^{105}$ the oriental significance of the reclining banquet passed into the Greek world: as an attribute of Near Eastern royal decorum, the symposium remained in archaic Greece an essentially aristocratic practice, designed to distinguish between the elite and the commoners, both in everyday life and in the visual code of social representations. With Oswyn Murray, the symposium gained an anthropological dimension as a 'functional group' having a social role to play in archaic societies. ${ }^{106}$ If the Homeric symposium was mainly an association of elite warriors (considered as an example of Heinrich Schurtz's Männerbund), it became in the archaic city the refuge of a leisure class. According to Murray, the archaic symposium belongs to the life and private domain of the archaic elite, where aristocrats met among peers and enjoyed the refinement of winedrinking parties with the performance of poetry, music, and sexuality, both heterosexual and homosexual. Symposia not only reflect the taste and inclinations of the aristocracy, they enabled the aristocrats to distinguish themselves from the rest of the polis. More significantly, on a civic level, the symposium became 'a form of political organisation in response to the emergent city-state, designated to perpetuate aristocratic control of the state against the demos, a small group working against the community'. ${ }^{107}$ Leslie Kurke and Ian Morris have further elaborated this aristocratic interpretation on an ideological level, assuming that the archaic Greek symposium served as the site for an anti-polis ideology. ${ }^{108}$ Accordingly, there should be no positive relation between the practice of the symposium and the definition of archaic citizenship.

However, François Lissarrague and Pauline Schmitt-Pantel have contributed to establishing a more balanced view. Looking at Greek vases both as an historian and as an anthropologist in the tradition of La cité des images, ${ }^{109}$ François Lissarrague has devoted numerous studies to visual representations of the symposium on archaic and classical pottery. ${ }^{110}$ Whether by analogy or through the use of alterity, Greek images tend to figure the world of the symposium as a microcosm of the polis, as a representation of what it should be or what it should not be. Elaborating on Lissarrague, Pauline SchmittPantel insisted on the political dimension of the symposium: banquets are a perfect example of collective activity that has an immediate connection with the political sphere of the polis. According to her, "in the aristocratic Greek city of the archaic period, participation in a set of collective activities is the sign of belonging to the group of citizens, without of course being the only requirement for membership'. If the symposium remains the privilege of a small minority in archaic Greece, banqueting also contributes to the construction of

\footnotetext{
105 Dentzer 1982, esp. 429-52 (Le banquet et l'idéal aristocratique).

106 Murray 1983a; 1983b; 1983c; 1990c; 1993a, 207-13. ${ }_{107}$ Murray 1983b, 266.

108 Kurke 1999a; Morris 2000, 183. See also the critiques of Hammer 2004 and Kistler 2004.

109 Bérard et al. $1984 . \quad{ }^{110}$ Lissarrague 1987; 1999.
} 
the citizen space, as the cases of the Cretan and Spartan syssitia make clear, where access to the common meal is both a sign and a criterion of citizenship. Both Cretan cities and Lycurgan Sparta institutionalized the aristocratic symposium because it entails an essentially political nature, still reflected for example in the opening section of Plato's Laws: 'in a symposium the procedures and conventions are those of political life'. As seen by Schmitt-Pantel, banqueting was definitely an activity of the archaic citizen: beyond the religious aspect of the symposium, 'access to the shared experience and the equal distribution identifies the man who benefits from it and makes him an equal member of the social group, indeed of the civic group, the polis' or, more synthetically, 'to have a share in citizenship is to share in a banquet'. ${ }^{111}$ In short, although concurring on the aristocratic origin of the banquet, the two models of Murray and Schmitt-Pantel diverge on the ideological involvement of archaic elites in politics and the purpose of their collective gatherings. Instead of casting the symposium as an anti-polis association, the 'École de Paris' assimilates symposiasts to avatars of citizens.

Aiming at combining the aristocratic and the civic aspects of the symposium into a unified model, Marek Węcowski recently shed new light on the subject. ${ }^{112}$ Although he confusingly keeps the word 'aristocracy'-too heavily biased by ancient Greek political thought and a century of modern scholarship $^{113}$ - he gives to it a radically different meaning, based on the sixteenth- to eighteenth-century Polish and Lithuanian aristocracy (locally and idiosyncratically named szlachta), whose composition and behaviours are close to the notions of 'elite' and 'modes de reconnaissance sociale' that I promoted in my own studies. ${ }^{114}$ In line with the idea that social status was fluid and contested in early Greece, Węcowski nevertheless argues that the symposium allowed for the resolution of the resulting tensions thanks to an emphasis on equality and turn-taking. The circulation of cups, of speech, of turns in drinking games reflects the egalitarian ethos that made the symposium, serving to integrate upwardly mobile farmers within the warrior elite, but also enforcing equality among the group of drinkers and within the citizen community.

In Greek images as in Near Eastern art, the representation of hunting has usually been interpreted as the depiction of a noble activity. 'Happy is he who has dear boys, horse of uncloven hoof, hunting dogs, and a friend in foreign parts,' sang Solon (fr. 23 West). Hunting is thus normally associated with the behaviour of an aristocratic leisure class, while its depiction in texts and art is supposed to represent aristocratic ideas of masculinity and adulthood. ${ }^{115}$ However, hunting also plays a major part in the practices associated with

111 Schmitt-Pantel 1990a, 201. See also Schmitt-Pantel and Schnapp 1982; Schmitt-Pantel 1990b; 1992.

112 Węcowski $2014 . \quad 113$ See now Fisher and van Wees $2015 \mathrm{~b}$.

114 Duplouy 2006a. See above, section 3. $\quad 115$ Recently, Barringer 2001. 
the origins of ephebic activities. As Pierre Vidal-Naquet demonstrated in The Black Hunter, hunting belongs to the "practices of "apprenticeship", whose object was to introduce young men to their future roles as citizens and heads of families-that is, as full members of the community.' ${ }^{116}$ Hunters are young men on the threshold of adult life and hunting in the borderlands of Greek cities (eschatiai) defending the frontier area was an essential step in the military training that was the privilege of citizens. Adapting Vidal-Naquet's anthropological approach to the study of images, Alain Schnapp shows how the representation of hunting was associated in archaic and classical visual arts with a specific group, which is not an elite group but an age group. ${ }^{117}$ In Homer, heroes never hunt to demonstrate the exclusivity or nobility of their lifestyle; they hunt to survive in hostile conditions or to protect flocks and their own life. In the world of cities hunting becomes part of the training for citizens. Unlike Near Eastern reliefs or late classical wall paintings (such as the frieze of Tomb II in Vergina), sixth- and fifth-century Corinthian and Athenian vase-painters always depict hunters as young beardless men, clearly alluding to the world of the ephèbeia. By tightly connecting hunting and eros, images also reinforce the strong educational content of this apprenticeship period in the life of a young man. Homosexual pederasty links an erastēs and an eromenos, that is, an adult citizen and a citizen-to-be. In archaic Greek images, whether referring to myths or to everyday life, hunters are definitely young people learning their role as citizens.

To conclude this section on collective behaviours and their representation in visual arts, let me again quote Pauline Schmitt-Pantel: 'in archaic societies collective activities like banquets, hunting, and educational apprenticeships are part of the conception of citizenship. They are not only the way to bring citizens together, to introduce them to one another, and to create ties which are not simply those of the neighbourhood or of kinships, they are also part of a whole set of forms of conduct which makes it possible to distinguish between citizen and non-citizen. ${ }^{118}$ Rejecting the oriental models, Greek painters were able to relocate the visual representations of hunting and banqueting in a brand new world, that of the archaic polis. By giving new values to these exclusive behaviours they contributed to the definition of an undoubtedly original form of citizenship. In interpreting visual arts, historians and art historians are more and more inclined to link images and citizenship, whether by strengthening the connections between the depiction of human figures and citizens or by establishing an immediate relationship between a specific style and a precise citizen identity.

Elaborating on a suggestion made by Bruno d'Agostino, the Italian School of Archaeology in Athens (Scuola Archeologica Italiana di Atene) organized a

116 Vidal-Naquet 1986 (quotation, 106).

118 Schmitt-Pantel 1990b, 210.

117 Schnapp 1979a; 1979b; 1997. 
conference in order to discuss a possible link between the development of a figured imagery and the dawn of the Greek city. ${ }^{119}$ As is well known, figured images are much less frequent after the collapse of the Mycenaean palatial system, even if twelfth-century (LH III C) pieces are known, such as the spectacular warrior vase from the acropolis of Mycenae or the more humble figured fragment recently exposed in the new excavations of LefkandiXeropolis. ${ }^{120}$ With the exception of Early Iron Age Crete (early tenth-century krater from Thronos Kephala and ninth-century Knossian Protogeometric $\mathrm{B}^{121}$ ) and Euboea (the famous late tenth-century Lefkandi centaur), in most of the Greek mainland a figured repertoire did not reappear before the late Geometric period. The so-called 'Greek Renaissance' of the eighth century therefore also embraces the rebirth of figured images in visual arts. Luca Cerchiai's and Francis Croissant's contributions are certainly two of the most stimulating papers in the volume. Although he is mainly concerned with the birth of the Etruscan city-state, Cerchiai explains how the creation of an Etruscan figured imagery contributed to the redefinition of the elite role in the ruling of the new urban communities of archaic Etruria. ${ }^{122}$ In this process Greek images were used as a tool of integration, offering models of a political society ranked by age, gender and social functions. In particular, he shows how images of board game players became a sign of citizenship in the Etruscan iconographic code. In archaic Greece, indeed, the draughtboard was often conceived of as a metaphor of the city and the pieces (pessoi) of the citizens, the civic symbolism being inherent already in the names and structure of some of these games (incidentally, one of them was named polis). As Leslie Kurke expresses it, "for (some) Greeks of the archaic and classical periods, playing pessoi taught the player how to be a citizen in the polis. ${ }^{123}$ Besides Exekias' famous amphora depicting Ajax and Achilles throwing dice on a board the iconographic type of the board game-playing heroes was actually very popular in archaic Greece. It sheds some light on 'emic' conceptions of citizens and polis, light years away from any legal or institutional approaches. In a very different field, Francis Croissant demonstrates how a figured imagery and a new distinctive Parian style were purposely created in the context of a public funeral that clearly reveals the existence of a citizen community in late Geometric Paros. ${ }^{124} \mathrm{He}$ draws attention to two Geometric amphorae discovered in a multiple burial resulting from a single deposition in the last quarter of the eighth century of at least 150 young men. This burial, probably

119 d'Agostino $2008 . \quad{ }^{120}$ Lemos 2008, 181.

121 D’Agata 2008, 221; 2012. For Knossian Protogeometric B (PGB), see Coldstream, Eiring, and Forster 2001, 66.

122 Cerchiai 2008.

123 See Kurke 1999b (quotation, 260). See also Vernant 1988, 437 n. 123; Hansen 2002a. Some of these games also link back to the symposium, see Brock 2013, 93 and n. 91 .

124 Croissant 2008a; 2008b. 
related to some defeat (or victory?) on the battlefield against a neighbouring city (Naxos?), appears as an early form of dèmosion sêma, nearly 250 years before the institution of the Athenian patrios nomos. Even if only two of the 150 funeral urns deposited in the polyandrion were decorated with a figured imagery (and more precisely with battle scenes), they received no special treatment in the collective tomb itself. Yet, if they reveal some individual pretension to social prestige, they are also part of a new figured style emerging in late Geometric Parian pottery production. Those two amphorae indeed fit into a series of vases that stylistically express a clear-cut Parian identity as early as the late eighth century. Artistically, both the birth of images and the definition of a distinctive style make conspicuous the dawn of the Parian state.

Anticipating Josine Blok's statement-based on terminology (see above, section 4)-on the prominence of collective identity in defining archaic citizenship, Francis Croissant's work is also a milestone in making styles in archaic arts and crafts a key feature in defining citizen identities among the Greek world. The initial statement and theorization go back to Ernst Langlotz's seminal book on archaic 'schools of sculptors' (Bildhauerschulen), whose nature and course can often be likened to those of Italian Renaissance schools of painting. Contrary to the idea of a predominantly personal style for every single artist or to that of a general chronological evolution, he demonstrated how archaic sculptures, bronze figurines, and terracottas could actually fit into various 'schools' and how their style could be assimilated to a specific citizen identity: 'Die Einschätzung des Künstlers ist begründet in der Bindung und Sammlung aller Kräfte in dem Brennpunkt des hellenischen Lebens: dem Staate. ${ }^{125}$ Cataloguing hundreds of plastic works known to his time he proposed an ambitious taxonomy of archaic styles. If numerous studies in theoretical archaeology and ethnology discuss the meaning of styles in various societies, ${ }^{126}$ past or present, they usually disregard Greek art as irrelevant to a social approach to material culture and never mention Langlotz's essay; conversely, they cannot offer ready-made models for the historical peculiarity of the archaic Greek world. However, the link postulated in 1927 by Langlotz between school, style, and city has been widely confirmed by later discoveries and specified by more recent studies applying his methodology to other classes of materials: Geometric bronze figurines and pottery, as well as archaic bronzes and terracottas. ${ }^{127}$ Of course, the vocabulary formerly used by Langlotz, often referring to 'race' or 'blood', is now old-fashioned and duly subject to criticism. It is now commonplace to talk of 'cultural identity' instead and to

125 Langlotz 1927, 7. Unfortunately ignored by Osborne 2011, 108-111 in his discussion of civic identity in archaic sculpture, misinterpreting the chronological groups of Richter 1970.

126 See for example Wiessner 1983; Conkey and Hastorf 1990; David and Kramer 2001, 168-224.

127 Herrmann 1964; Rolley 1983, esp. 131-2; Coldstream 1983; Croissant 1983. 
consider that culture and specifically visual arts belong to the realm of the polis. ${ }^{128}$ More precisely, according to Claude Rolley, on an individual level, artists and craftsmen were citizens, conscious of their citizen status and deliberately expressing it through the style of their creations. ${ }^{129}$ Even if peculiarities have been specified for various areas (particularly for the Western colonies ${ }^{130}$ ) and if artistic identity has to be adapted to the rules of social agency and travelling workshops, ${ }^{131}$ a close connection between style and citizen identity may still be accepted. Some scholars have nevertheless denied such a political link between material culture and the mosaic of Greek cities, preferring the loose concept of 'regional style' (usually known in German literature as Landschaftsstil and opposed to Zeitstil) that would be common to several artistic centres without distinct identities. ${ }^{132}$ By emphasizing the notion of 'region', scholars disconnect art from politics to the benefit of geography alone. As Francis Croissant writes, 'considérer que les Cyclades, par exemple, constituent une "région" peut paraître tout naturel, mais il serait vain de chercher à définir clairement une identité "cycladique", que ce soit à partir des céramiques du $\mathrm{vI}^{\mathrm{e}}$ siècle ou des sculptures du $\mathrm{vI}^{\mathrm{e}}{ }^{.}{ }^{133}$ In such wide cultural areas, archaic arts and crafts normally present a variety of styles with distinct characteristics and radical oppositions, whose birthplace may be identified.

Emphasizing the need to set early Greek art and material culture in its cultural and social context, Ian Morris developed, some fifteen years ago, a globalizing model made of two antithetical ideologies: the middling and the elitist. ${ }^{134}$ The middling tradition goes back to Hesiod, for whom privileges, restraint, and moderation were the keys to a good life. Such an ideal is 'defined against the specters of the desperate poor and the greedy, hubristic rich' and forms the core of a 'citizen ideology' that would last until the fourth century at least. The rival ideology, the elitist tradition, begins with Homer. It regulates the world of the aristocracy as 'one of delicacy, elaborate manners, sweet perfumes, and wealth' with 'strong Eastern influences'. Morris uses archaic poetry to show how central the 'East' was for both elite and middling poets, who either praised or disdained oriental models and influences. Since 'there was no way to transcend the polis in the middling tradition', the 'art of citizenship' would thus be assimilated to rejecting Orientalizing art and values beyond the realm of the polis and confining it to the interstices of the polis

\footnotetext{
128 See Boardman $1995 . \quad 129$ Rolley 1983-4.

130 Croissant 1992 coined the notion of 'éclectisme inventif' to qualify Greek colonial styles, which has been regularly applied thence.

${ }^{131}$ Viviers 2002; Duplouy 2006a, 217-49; 2006b; 2006c.

132 Snodgrass 1999; Whitley 2001, 231-3 following the division into four macro-regions proposed by Morris 1998.

133 Croissant 2007 (quotation, 30).

134 Initially presented in Morris 1996 and 1997 (quotation from 11, 12, 16, 42). For later developments and critiques of the model, see Duplouy this volume (chapter 10).
} 
world, at interstate games, in ritualized foreign friendship, behind the doors of the aristocratic symposium, or in sanctuaries located outside the political space of the city-state. The well-known shift in the deposition of valuables from graves to sanctuaries in eighth-century central Greece could indeed be interpreted both as a success for the emerging citizen community, removing them from other social contexts, and as an attempt by the elite to bring such forms of 'antisocial behaviours' back into the heart of the polis. Exploring how Orientalizing art was used, Morris assimilates the Orientalizing movement to 'a class phenomenon' and identifies different regional patterns of responses, arguing that the social transformation was most intense in central Greece, although it affected other areas as well: 'The meaning of Orientalizing art must have been very different in Crete from those in the Aegean. In central Greece, the use of Orientalizing art created an oppositional group alienated from, but claiming to stand above, the world of the cities. In Crete it spoke of continuity.'

Such a discrepancy between these two regions has been further elaborated by Thomas Brisart, who sought to combine Morris' dichotomic model with my own work on archaic elites. Defining what he calls a 'citizen art', Brisart shows how Orientalizing objects were used in archaic cities as formal tools regulating the dynamics between the elite and the rest of the population: 'Pour être plus précis, ils étaient utilisés dans le cadre d'institutions étroitement liées à l'émergence de la citoyenneté à laquelle on assiste à la même époque."135 Following Morris in proposing two models of polis formation, he relates them closely to two different uses of Orientalizing art in society, but disagrees with him on the nature of archaic aristocracies and avoids reproducing a notion I deconstructed. In central Greece or 'agonistic cities' the elite was deeply embedded into the new citizen body and used Orientalizing artefacts as strategies of distinction (referring to my own 'modes de reconnaissance sociale') within the process of a never-ending social competition between citizens. In Crete, on the contrary, citizens and the elite being one and the same social body, Orientalizing art was extended to all the citizens and used as a means of reinforcing the cohesion of the citizen body and of marking the gap between that elite and the rest of the population. As Brisart concludes, 'L'art orientalisant constituait, en Crète, un vocabulaire visuel propre à la cité, un art exclusivement réservé aux citoyens. Il servait ainsi, au même titre que les autres institutions civiques, à assurer la cohérence de la citoyenneté mais aussi à établir une césure entre celle-ci et le reste de la société. ${ }^{136}$ Orientalizing art was also a citizen art.

Defining archaic citizenship is not only the task of historians. Archaeologists and art historians too can take the discussion a step further thanks to the awareness of the very strong and active role of material culture in shaping 
social and political identities. The importance of human agency in the mediation of local identities and social statuses has been acknowledged-see Alfred Gell's seminal book Art and Agency ${ }^{137}$-and offers the possibility of ascribing to material culture, intended as a 'total social fact', a sound historical value. It could also force historians to reconsider in new ways classical problems of ancient history.

\section{NEW PATHWAYS TO ARCHAIC CITIZENSHIP}

Defining archaic citizenship is of course a way to think about the archaic polis. Its image has considerably changed in the last decades as different approaches progressively evolve and eventually converge. ${ }^{138}$ Having reviewed major patterns of citizenship definition in most of twentieth-century historiographyalthough with no claim to be exhaustive and while developing, admittedly, a personal approach to the question-it is easy to acknowledge both the advances made in a century of scholarly research on archaic Greece and the many different schools of thought that are still debating the very nature of archaic citizenship. If the Aristotelian model has long been applied to all Greek cities regardless of chronological issues, more and more historians are now challenging Aristotle's theoretical definition and are looking for other ways of conceiving citizenship and community. The greatest difficulty is certainly to reformulate in a completely different manner both the questions and the answers to achieve new sorts of definitions of citizenship.

Recent studies, indeed, have produced new pathways to archaic citizenship that are significantly different from the juridical and institutional approach of late nineteenth-century Griechische Staatskunde, with the notable exception of the Copenhagen Polis Centre. As Adele Scafuro puts it, 'the description of a study as "constitutionalist" or as "focused on institutions" nowadays commonly insinuates narrowness' and 'many of the questions that are now being asked about citizenship are different from those asked sixty years ago'. ${ }^{139}$ By analogy with economic historiography, I would say that an old 'formalist' attitude towards archaic citizenship, observing it through the eyes and with the concepts of a classical scholar such as Aristotle, has now often been replaced with a 'substantivist' approach, more respectful of the peculiarities of archaic societies and the diversity of ancient documents, from texts to material culture. The archaic city is no longer considered by specialists as a kind of primitive or unachieved classical polis. At least, we might hope so.

137 Gell 1998. For a case study on ancient Greece, see Whitley $2006 \mathrm{~b}$.

138 Davies 2009. 
This volume aims to contribute to this trend and to the growing emphasis on diversity. The essays collected here have not been tailored, however, to endorse any view. In the following pages, each contributor brings his or her own (national) background and develops a particular approach to archaic citizenship through specific fields of enquiry. John Davies (chapter 2) addresses the difficult question of state formation in Early Iron Age Greece by investigating the 'operative forces'. Josine Blok (chapter 3 ) distinguishes between the foundational role of cult, the formative role of descent, and the structuring role of law in shaping a genuinely archaic form of citizenship. Addressing the role of warfare in defining the citizen status, especially in Solonian Athens, Hans van Wees (chapter 4) argues for the existence of very strict military obligations in archaic cities. Paulin Ismard (chapter 5) shows how important the associations of archaic Athens were in mediating a citizen affiliation to the polis, ultimately revising the meaning of the Cleisthenic reform. Similarly, Marcello Lupi (chapter 6) argues that the Spartan civic subdivisions were used to ensure a rational organization of the citizen body, defining the respective roles played by membership of civic subdivisions and participation in collective practices in the construction of Spartan citizenship during the archaic period. Bringing forward the case of Sparta, Paul Cartledge (chapter 7) lays bridges between ancient and modern citizenship theory. Nick Fisher (chapter 8) emphasizes the strong civic nature of athletics from the sixth century on, which led various cities to offer enfranchisement to foreign victorious athletes. James Whitley (chapter 9) reviews all the literary, epigraphic, and archaeological evidence pertaining to the andreion in Cretan cities and stresses the peculiar patterns of Cretan citizenship. As both editor and contributor to this volume, I propose to evaluate archaic citizenship as a performance, rather than as an assigned status enshrined in legal criteria, stressing the significant role of horse-breeding and luxury behaviours in various archaic cities (chapter 10). And finally, before the concluding remarks of Roger Brock (chapter 12), Maurizio Giangiulio (chapter 11) discusses the so-called fixed-number oligarchies, which he prefers to assimilate to citizen bodies that adopted a highly symbolic name and shape, rejecting the usual distinction between a ruling elite with full political rights and a mass of underprivileged people.

How helpful is this diversity of approaches and opinions in defining archaic citizenship? Is it necessary to make more complex an issue that was already settled through the Aristotelian model? As Umberto Eco once wrote in Foucault's Pendulum, 'for every complex problem there's a simple solution, and it's wrong'. Defining archaic citizenship certainly implies venturing off the beaten track. So, yes, far from diluting the subject, this diversity ofsupplementing and/or conflicting-approaches is both sound and necessary.

If there are multiple ways of exploring archaic citizenship, it should be stressed that conditions were very different too from one city to another in 
archaic Greece. First, being a citizen in Sparta, Gortyn, or Chalcis was not the same experience as enjoying citizen status in Athens, Samos, or Sybaris. Second, the Early Iron Age communities discussed by John Davies did not have the same contingencies as late sixth- or early fifth-century poleis discussed by many other contributors. And third, there might also have been diverging notions of citizenship among the members of the same archaic polis. As Josine Blok writes for classical Athens, 'Es gab in Athen, so meine These, einfach verschiedene Auffassungen vom Bürgerstatus. ${ }^{140}$

In sum, there are both various modern approaches to archaic citizenship and various existing models in archaic Greece. It is the hope of this volume of collected essays to express this diversity. To fully understand citizenship in archaic Greece we perhaps ought, eventually, not to choose between various conflicting definitions, but rather to combine the different perspectives in a single historical attempt. As both editors hope, the whole volume should be more than the mere sum of its parts.

\section{ACKNOWLEDGEMENTS}

The main part of this chapter was written in 2011 thanks to a Fulbright visiting scholarship at the University of California, Los Angeles. My warmest thanks go to Sarah Morris and John Papadopoulos, who were invaluable hosts, particularly in the darkest days of this American experience. The chapter was further elaborated over the years thanks to the generous comments of Roger Brock and Hans van Wees. Although such a broad topic encompasses countless conflicting views and critical nuances, references in footnotes are deliberately restricted. 